\title{
Hydroclimatic dynamics in southwestern Romania drylands over the past 50 years
}

\author{
Remus PrăvăLie ${ }^{1, *}$, Liliana Zaharia ${ }^{2}$, Georgeta Bandoc $^{1}$, \\ Alexandru I Petrişor ${ }^{3,4}$, OAna IONUŞ 5 and IUlian Mitof ${ }^{2}$ \\ ${ }^{1}$ Bucharest University, Faculty of Geography, Center for Coastal Research and Environmental Protection, \\ Meteorology and Hydrology, 1 Nicolae Balcescu Blvd., District 1, 010041, Bucharest, Romania. \\ ${ }^{2}$ Bucharest University, Faculty of Geography, 1 Nicolae Balcescu Blvd., District 1, 010041, Bucharest, Romania. \\ ${ }^{3}$ Ion Mincu University of Architecture and Urbanism, 18-20 Academiei Blvd., District 1, 010014, Bucharest, \\ Romania. \\ ${ }^{4}$ National Institute for Research and Development in Constructions, Urban Planning and Sustainable Spatial \\ Development URBAN-INCERC, 266 Pantelimon Blvd., District 2, 021652, Bucharest, Romania. \\ ${ }^{5}$ Craiova University, Faculty of Geography, Al. I. Cuza Blvd., 1100, Craiova, Romania. \\ ${ }^{*}$ Corresponding author.e-mail: pravalie_remus@yahoo.com; geobandoc@yahoo.com
}

The present paper examines hydroclimatic dynamics in southwestern Romania drylands, which is one of the country's most heavily affected regions by climate change. The analysis focuses on two of the region's representative catchments (Drincea and Desnatui), covers the past five decades (1961-2009), and is based on climate data (mean monthly and annual climatic water balance values - CWB, expressed in $\mathrm{mm}$ ) and hydrological data (mean monthly and annual streamflow rate values - SFR, expressed in $\mathrm{m}^{3} / \mathrm{s}$ ). The data were provided by five regional weather stations, i.e., by five gauging stations located within the two catchments. The analysis was conducted on three temporal scales (annual, seasonal and monthly), and used statistical methods, such as Mann-Kendall test/Sen's slope method for trend analysis, and Spearman/Student test for the statistical association between climatic and hydrological parameters. The results indicated an overall increase in climatic water deficit, with direct effects on streamflow reduction. Statistically significant trends (climatic water deficit increase and streamflow decrease) were identified especially in spring (with maximum rate values of $(-1.66 \mathrm{~mm} / \mathrm{yr}) /(-81.3 \mathrm{~mm} / 49 \mathrm{yrs})$, for the CWB, and $\left(-0.02 \mathrm{~m}^{3} / \mathrm{s} / \mathrm{yr}\right) /\left(-0.9 \mathrm{~m}^{3} / \mathrm{s} / 49 \mathrm{yrs}\right)$, for the SFR). In some cases (mainly in the autumn months) it was found that, while climatic water deficit has decreased, the streamflow rate has increased. Statistical correlations revealed the relationship between the considered hydroclimatic parameters, with a particularly high statistical significance in spring and summer. Weak and inverse correlations between climatic and hydrological parameters can be explained by the role of other factors controlling the streamflow, both natural (soil and lithology) and anthropogenic (wetland drainage, water body conversion, dam and reservoirs building).

\section{Introduction}

It is unanimously accepted that Earth is currently experiencing a series of both global and regional environmental changes, which intensified, especially after 1950, in the so-called Great Acceleration period (Kolbert 2011; Steffen et al. 2011). Changes in climatic parameters represent one of the most

Keywords. Hydroclimatic dynamics; trends; statistical correlations; southwestern Romania; drylands; Drincea River; Desnatui River. 
important global environmental issues, and this is due, mainly, to anthropogenic $\mathrm{CO}_{2}$ emissions, whose concentration increased in the atmosphere from approximately $280 \mathrm{ppm}$ in the $1800 \mathrm{~s}$, to $370 \mathrm{ppm}$ in the 2000s (Sterman and Sweeney 2007; Crueger et al. 2008), and to about $400 \mathrm{ppm}$ at present (Molyneux et al. 2012; CDIAC 2014).

As the climate and hydrological systems are closely interconnected in terms of water and energy balances, disturbances affecting the main climatic parameters (overall temperature increase and rainfall rate decrease in numerous regions worldwide) have a direct or indirect impact on water resources, which are of paramount importance, both socioeconomically and environmentally. This impact is mainly reflected by changes in hydrological parameters and river streamflow regimes. Thus, in the context of rainfall rate decrease, a water discharge diminution was noticed in various regions of the globe (e.g., vast areas in Africa, southern and southeastern Europe, eastern and southeastern Asia and eastern Australia) (Gou et al. 2007; Dai et al. 2009; Ma et al. 2010; Hannaford et al. 2013; He et al. 2013). There are, however, cases when the river streamflow has grown in areas experiencing increasing rainfall rates, over recent decades, such as certain areas of northern Eurasia, northern North America, southern South America and eastern Africa (Genta et al. 1998; Lins and Slack 1999; Groisman et al. 2001; Peterson et al. 2002; IPCC 2007; Pasquini and Depetris 2007).

Another important effect of climate change is the disruption of hydrological regimes, in the context of global warming. A relevant example is the accelerated occurrence of high spring waters as a result of temperature rise and snow melt in upper catchments (Cayan et al. 2001; Zhang et al. 2001; Burn and Hag Elnur 2002; Hodgkins et al. 2003; Barnet et al. 2005; Stewart et al. 2005; Zaharia and Galie 2007; Bîrsan 2013, 2014; Perju et al. 2013a, b). Some of the regions most sensitive to these hydroclimatic perturbations are western U.S., Canadian Prairies, the Andean region of South America, the Himalaya-Hindu Kush region, and even central and northern Europe (Barnett et al. 2005).

In the future, according to climate scenarios, it is estimated that regions such as mid-latitude western North America, southern Europe, southern Africa, the Middle East will experience a decline in streamflow $(10-30 \%)$ by 2050 , while in others regions (southern South America, eastern equatorial Africa, high latitude regions in North America and Eurasia), the river streamflow rates will increase by 10-40\% (Milly et al. 2005).

In Romania, previous studies conducted in various areas revealed connections between climate and streamflow variabilities over the past decades (Rîmbu et al. 2002; Ştefan et al. 2004; Ghioca
2008, 2009; Neculau and Zaharia 2009; Zaharia and Beltrando 2009; Chendeş et al. 2010; Ciuinel and Onţel 2012; Bîrsan et al. 2014; Mitof and Prăvălie 2014; Prăvălie et al. 2015). Recent studies conducted on a large number of catchments, showed that, overall, in the last half century, seasonal streamflow decreased during spring and summer, while it increased during autumn and winter (Bîrsan et al. 2012, 2014; Bîrsan 2013). This can be explained by the climate change affecting the country especially in the second half of the 20th century, i.e., temperature rise in winter, spring and summer, and increase in rainfall rate in autumn (Busuioc et al. 2009, 2010). While the streamflow rise in autumn and winter is caused by increased rainfall (rise in rainfall during winter as a result of increase in temperature), the spring and summer streamflow decrease is a consequence of the snow layer diminution and increased evaporation, respectively (Bîrsan 2013; Perju et al. 2013a, b; Bîrsan et al. 2014).

The present paper aims to analyse trends of hydroclimatic dynamics and the relationship between the variation of certain climatic and hydrological parameters in the southwestern Romania drylands, over the past five decades (1961-2009). The study area is an important agricultural region of Romania, where climate change and the related hydrological impact can have major consequences (socio-economic and ecological), which makes this study both relevant and original, as no such approach has ever been made for this region, at the given spatial and temporal scales.

\section{Study area and major hydroclimatic features}

The study area is located in southwestern Romania (figure 1a). The analysis focuses on two of the region's main catchments - Drincea $\left(735 \mathrm{~km}^{2}\right)$ and Desnatui (2044.4 km²) (Prăvălie et al. 2015). The two main rivers are tributaries of the Danube River. The catchments' lower sectors overlap the Oltenia Plain (western subunit of the Romanian Plain), while the upper ones overlap the Balacita Piedmont (subunit of the Getic Plateau) (figure 1a, b).

In terms of altitude, landforms span over $327 \mathrm{~m}$ (with a maximum value of $348 \mathrm{~m}$ above the m.s.l. in the plateau area, and a minimum value of about $20 \mathrm{~m}$ above the m.s.l. in Danube's floodplain, which constitutes the southern border of the Oltenia Plain), with generally low slopes (at most $20^{\circ}$ in valley sectors). Although an important feature of the Oltenia Plain landforms is related to the presence of sand deposits, which can, however, have a major impact on runoff by favouring infiltration, 


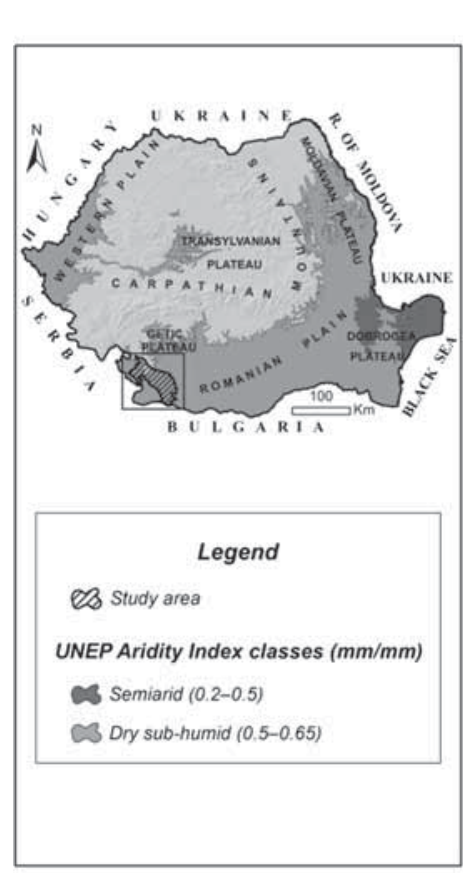

(a)

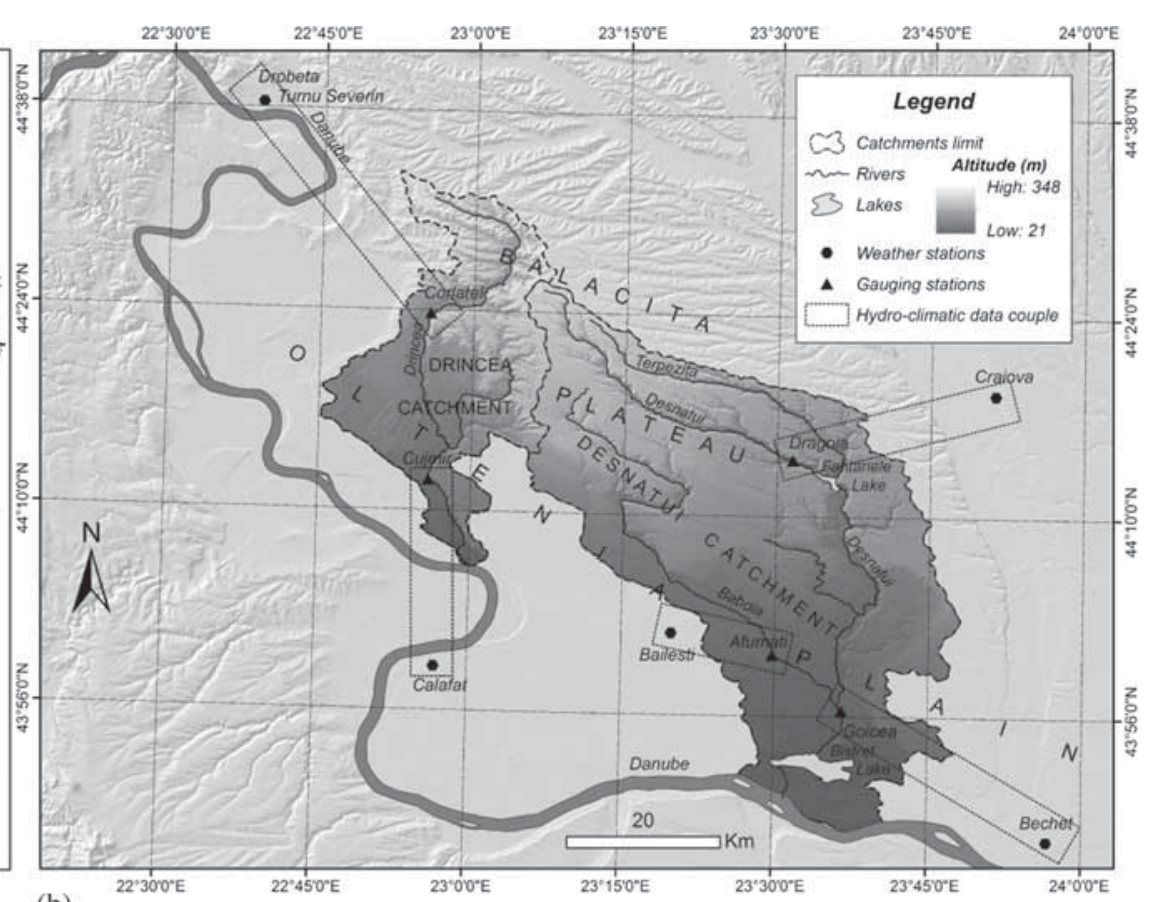

(b)

Figure 1. (a) Location of the study area in Romania and spatial representation of the UNEP (United Nations Environment Programme) Aridity Index $(\mathrm{mm} / \mathrm{mm})$ at country level and (b) the locations of the analysed weather/gauging stations in the study area.

streamflow in the catchments analysed is influenced by this to a lesser extent, considering that these deposits are mainly present in the vicinity of the study area.

The study area is characterised by a temperate continental climate with oceanic and Mediterranean influences that generate greater amounts of precipitation in the country's southwestern region and higher temperatures, compared with other regions in southern Romania (Sandu et al. 2008). Mean multiannual temperatures range from 11 to $12^{\circ} \mathrm{C}$, with a lower interannual coefficient of variation than the same of rainfall (table 1). Annual rainfall amounts range from 500 to $670 \mathrm{~mm}$, with an interannual coefficient of variation of $20-25 \%$ (table 1 ). The temperature regime is characterised by minimum values in January and maximum values in July (figure 2a). With regard to rainfall, the highest values are specific to May and June, and the lowest to January and February (figure 2a).

In terms of climatic aridity, the two catchments overlap by more than $80 \%$ of dry sub-humid areas (figure 1a), which is a characteristic of the country's southwestern region (Prăvălie et al. 2016). This dryland class, defined by the ratio between precipitation and potential evapotranspiration (according to the UNEP Aridity Index) falling into the 0.5$0.65 \mathrm{~mm} / \mathrm{mm}$ interval (considering the 1950-2000 multiannual period) (Trabucco and Zomer 2009), is a major restrictive factor for local water resources, given the significant climatic water deficit.
Table 1. Data on analysed weather stations and main climatic parameters (1961-2009 period).

\begin{tabular}{lccccc}
\hline $\begin{array}{l}\text { Weather } \\
\text { stations }\end{array}$ & $\begin{array}{c}\text { Altitude } \\
(\mathrm{m})^{*}\end{array}$ & $T\left({ }^{\circ} \mathrm{C}\right)^{* *}$ & $\begin{array}{c}P(\mathrm{~mm}) \\
* *\end{array}$ & $\begin{array}{c}\mathrm{Cv} T \\
(\%)^{* *}\end{array}$ & $\begin{array}{c}\mathrm{Cv} P \\
(\%)^{* *}\end{array}$ \\
\hline $\begin{array}{l}\text { Drobeta Turnu } \\
\text { Severin }\end{array}$ & 78.2 & 12.2 & 667.5 & 5.4 & 20.9 \\
Calafat & 62.2 & 11.7 & 532.1 & 6.3 & 20.8 \\
Craiova & 193.2 & 11.3 & 514.1 & 6.2 & 25 \\
Bechet & 37.2 & 11.3 & 519.4 & 5.8 & 19.8 \\
Bailesti & 58 & 11.3 & 558.8 & 6.1 & 20.3 \\
\hline
\end{tabular}

$\mathrm{T}=$ Mean multiannual temperature; $\mathrm{P}=$ Mean multi-annual precipitations; $\mathrm{Cv}=$ Coefficient of variation.

*According to NMA (2014);

**based on data provided by Klein Tank et al. (2002) and NMA (2014).

Also, the rivers draining Oltenia Plain are generally short (most of them $<100 \mathrm{~km}$ long) and have a low density $\left(<0.3 \mathrm{~km} / \mathrm{km}^{2}\right)$ (Savin 2008). The main rivers are Drincea and Desnatui, originating in the Piedmont region (Balacita Piedmont) (figure 1b). While the rivers are supplied mainly by rainfall and snowmelt (up to $65 \%$ ), groundwater can also contribute, in certain cases, up to $45 \%$ of discharge (Pişota 2005).

Average multiannual streamflow (1961-2009) are low, with values ranging from 0.43 to $2.36 \mathrm{~m}^{3} / \mathrm{s}$, and significant interannual variations (table 2 ). Throughout the year, high discharge values are 

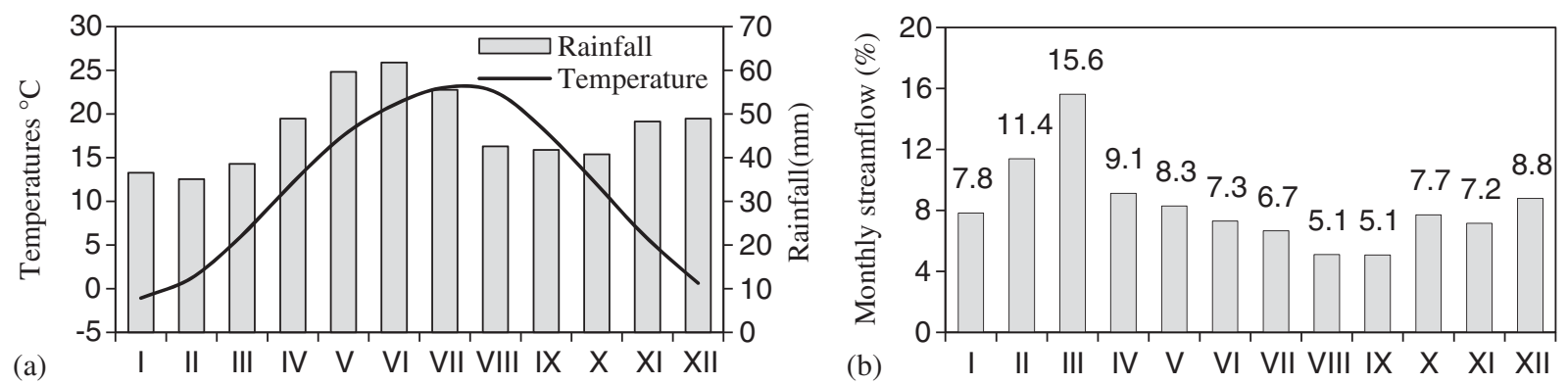

Figure 2. (a) Average multi-annual monthly temperature and precipitation variation (average values of the two parameters at the five weather stations between 1961 and 2009) and (b) average monthly discharge rate (\% of the average annual volume), between 1961 and 2009.

Table 2. Morphometric and hydrologic data on the analysed rivers.

\begin{tabular}{llcrlcc}
\hline \multirow{2}{*}{ River } & $\begin{array}{c}\text { Hydrometric } \\
\text { stations }\end{array}$ & $\begin{array}{c}\mathrm{L} \\
(\mathrm{km}) *\end{array}$ & $\begin{array}{c}\mathrm{A} \\
\left(\mathrm{km}^{2}\right) *\end{array}$ & $\begin{array}{c}\mathrm{Hm} \\
(\mathrm{m}) *\end{array}$ & $\begin{array}{c}\mathrm{Q} \\
\left(\mathrm{m}^{3} / \mathrm{s}\right) * *\end{array}$ & $\begin{array}{c}\mathrm{Cv} \\
(\%) * *\end{array}$ \\
\hline Drincea & Corlatel & 43 & 220 & 240 & 0.43 & 61.3 \\
& Cujmir & 10.4 & 680 & 195 & 0.91 & 48.7 \\
Desnatui & Dragoia & 53.7 & 216 & 170 & 0.45 & 61.3 \\
& Goicea & 10 & 1710 & 132 & 2.36 & 41.7 \\
Baboia & Afumati & 70 & 560 & 134 & 0.94 & 69.8 \\
\hline
\end{tabular}

$\mathrm{L}=$ Distance from confluence; $\mathrm{A}=$ Catchment's area until the gauging station; Hm = Catchment's mean altitude corresponding to the gauging station; $\mathrm{Q}=$ Mean multi-annual streamflow (1961-2009 period); $\mathrm{Cv}=$ Mean annual streamflow variation coefficient (1961-2009 period).

* According to National Institute of Hydrology and Water Management database (NIHWM 2014);

** Based on data provided by National Administration, Romanian Waters - Jiu Water Directorate (JWD 2014).

typical for winter and spring (with a maximum of $15.6 \%$ of the average annual volume in March), while the summer and autumn streamflow rates are low (with a minimum value of $5.1 \%$ in AugustSeptember) (figure 2b), driven largely by groundwater supply (Pişota 2005).

In the catchments studied, there are no major anthropogenic influences on streamflow. The most important one is the Fantanele reservoir on Desnatui River (figure 1b), which influences the downstream streamflow regime (at Goicea gauging station). This reservoir was built in 1973 and has a water volume of approximately 40 million $\mathrm{m}^{3}$.

Given the autochthonous nature of rivers and relatively low human interventions, the streamflow is strongly conditioned by the region's climatic particularities. Although oceanic and Mediterranean influences can have a positive impact on streamflow through higher rainfall amounts, local climatic particularities such as frequent warm air advection processes, generally originating from northern Africa (generating dryness and drought phenomena mainly in the plain region), and high temperatures (which increase evapotranspiration) (Ciulache 2005; Dumitrascu 2006) can create the premises of climatic stress on streamflow regime in this drylands area. This climatic stress has already caused major disruptions in recent decades to other environmental components (either ecological, such as forest ecosystems, or anthropogenic, e.g., agricultural systems) in southwestern Romania drylands, as signalled by certain studies based on the analysis of satellite images and statistical data series (Prăvălie et al. 2014a, b, 2016). Considering the large number of municipalities in the analysed catchments (about 130) and the fact that $83 \%\left(2314 \mathrm{~km}^{2}\right)$ of their total surface is being used as agricultural land (of which $80 \%$, i.e., $1855 \mathrm{~km}^{2}$, is arable land) (CLC 2006), maintaining optimal water resources in this region, in the context of changing climate over the recent decades (Dumitraşcu 2006; Bojariu et al. 2012; Prăvălie 2013a; Prăvălie et al. 2014b), is crucial for the socio-economic activities.

\section{Data and methods}

In order to quantify hydroclimatic dynamics and the relationship between climate conditions and streamflow, two major data categories were used climatic and hydrological.

The main climatic data consist of average monthly and annual values of air temperature, and monthly and annual rainfall amounts, recorded between 1961 and 2009 at five weather stations located in the vicinity of the two catchments: Drobeta Turnu Severin, Calafat, Craiova, Bechet and Bailesti (figure 1b, table 1). The data were provided by the European platform for climate data ECA\&D (European Climate Assesment and Dataset) (Klein Tank et al. 2002) for the Drobeta Turnu Severin and Craiova stations, and by the National Meteorological Administration (NMA 2014) for Calafat, Bechet and Bailesti stations. 
Based on these data, the climatic water balance (CWB) was computed as the difference between precipitation $(P)$ and potential evapotranspiration (PET). The potential evapotranspiration parameter $(\mathrm{mm})$ was computed based on average monthly temperatures with Thornthwaite's methodology (Thornthwaite 1948), based on the relationship (Sandu et al. 2008):

$$
\mathrm{PET}=16 \times\left(\frac{10 t}{I}\right)^{a} F(\lambda),
$$

where $t$ is the average monthly temperature $\left({ }^{\circ} \mathrm{C}\right)$; $I$ is the annual thermal index calculated using the formula $I=\sum_{n=1}^{12} i_{n}, i_{n}=(t / 5)^{1.514} ; a=6.75 \times$ $10^{-7} \times I^{3}-7.71 \times 10^{-5} \times I^{2}+1.79 \times 10^{-2} \times I+0.49$; and $F(\lambda)$ is the adjustment factor depending on the latitude and the month of the year.

Despite limitations of this method resulting from the neglect of other important factors influencing the evapotranspiration process (e.g., wind speed) (Bandoc and Golumbeanu 2010; Bandoc 2012), the method is advantageous due to the fact that it requires minimal data input, and generally provides satisfactory results, as was the case for the Romanian territories (Păltineanu et al. 2007; Bandoc et al. 2013; Bandoc et al. 2014; Prăvălie and Bandoc 2015). The CWB was considered to be an appropriate synthetic indicator for climatestreamflow relationship analysis, as it integrates essential climatic parameters (corresponding to the input and output processes of atmospheric humidity) influencing streamflow. A similar indicator was applied in previous studies conducted on Romanian territory, which aimed to identify the areas affected by drought and aridity based on humidity deficit values (Păltineanu et al. 2007, 2009; Prăvălie and Bandoc 2015).

Hydrological data consist of average monthly streamflow measured over the same period as the climatic parameters (1961-2009) at the Corlatel and Cujmir gauging stations located on the Drincea River, Dragoia and Goicea stations on Desnatui River, and Afumati station located on the Baboia River (tributary of the Desnatui River) (figure 1b, table 2). The data was provided by the 'Romanian Waters' National Administration, Jiu Water Directorate (JWD 2014). Also, the data was acquired in full for the entire period 1961-2009, except for the Afumati station (founded in 1964), for which the data was obtained for the period 1961-1963 by means of the regression method (based on the data corresponding to the closest station, Goicea), in order to cover the entire analysed period of 49 years. The streamflow values resulted in the hydrological parameter, streamflow rate (SFR).
In terms of methodology, the study includes three steps:

- hydroclimatic data series temporal variability analysis,

- identification and quantification of hydroclimatic trends, and

- analysis of the statistical relationships between climatic and hydrological parameters.

In the first step, the analysis of the two indicators' variability (CWB and SFR), over the entire period, was conducted both annually and seasonally through the Box-Whisker plot method (Boxplot). Differences in data series temporal variability are thus observed based on outliers (1.5 - IQR) and extreme values $(3 \cdot \mathrm{IQR})$ for each station $(\mathrm{IQR}=$ the interquartile interval). As a result, the variability of the median and of the third and first quartiles, as well as the minimum and maximum values, between which IQR is positioned as an intermediate trend indicator, was highlighted (Martin and Buishand 2012).

For a better visualisation, analysis and interpretation of temporal variations of the CWB and SFR, their monthly values were plotted graphically in a GIS-based vector grid (Cheval et al. 2003). The method, adapted for this particular study, implies the use of a parallel point grid consisting of 12 columns (which represent the number of months) and 49 lines (the number of years between 1961 and 2009), with each point containing the climatic/hydrological parameter's value corresponding to the intersection of rows and columns (Prăvălie et al. 2014b).

The second step aimed to identify and quantify hydroclimatic trends on three temporal scales - annual, seasonal (spring, summer, autumn and winter) and monthly, over the 1961-2009 period. The trend analysis was performed by means of the Mann-Kendall (MK) test, used to identify trend types and statistical significance levels, and of the Sen's slope method, applied for quantifying the magnitude of linear trends (Mann 1945; Kendall 1975). These methods were used in many studies on climatic and hydrological temporal variability in different regions of the world ( $\mathrm{Fu}$ et al. 2004; Kahya and Kalayci 2004; Bîrsan et al. 2005; Ling et al. 2011; Shahid 2011; Danberg 2012; Reiter et al. 2012; Bîrsan 2013; Croitoru et al. 2013; Dhital et al. 2013; Huang et al. 2013; Liu et al. 2013, 2014; Qi et al. 2013; Zhang et al. 2013; Marin et al. 2014; Mitof and Prăvălie 2014; Wagholikar et al. 2014; Zarenistanak et al. 2014; Bandoc and Prăvălie 2015; Palizdan et al. 2015; Prăvălie and Bandoc 2015; Sabzevari et al. 2015; Singh et al. 2015; Zhu et al. 2015). Data processing was performed with the Excel MAKESENS application, 
developed by the Finnish Meteorological Institute (Salmi et al. 2002). The application operates on two types of statistical analyses - upward or downward monotonic trend analysis using the MannKendall test, and linear trend slope quantification using Sen's non-parametric method (Gilbert 1987).

The Mann-Kendall test is based on Z statistics, which for series with more than 10 values, can be defined by the equation (Salmi et al. 2002)

$$
Z= \begin{cases}\frac{S-1}{\sqrt{\operatorname{VAR}(S)}} & \text { if } S>0 \\ 0 & \text { if } S=0 \\ \frac{S+1}{\sqrt{\operatorname{VAR}(S)}} & \text { if } S<0\end{cases}
$$

In the above equation, $S=\sum_{k=1}^{n=1} \sum_{j=k+1}^{n} \operatorname{sgn}\left(x_{j}-x_{k}\right)$, where $n=$ total number of years; $x_{j}$ and $x_{k}$ are the annual values for years $j$ and $k(j>k)$;

$$
\operatorname{sgn}\left(x_{j}-x_{k}\right)= \begin{cases}1, & \text { if } x_{j}-x_{k}>0 \\ 0, & \text { if } x_{j}-x_{k}=0 \\ -1, & \text { if } x_{j}-x_{k}<0\end{cases}
$$

and $\operatorname{VAR}(S)=\frac{1}{18}\left[n(n-1)(2 n+5)-\sum_{p=1}^{q} t_{p}\left(t_{p}-1\right)\right.$ $\left.\left(2 t_{p}+5\right)\right]$, where $q$ is the number of clusters; $t_{p}$ is the number of values in a cluster of order $p$.

A positive or negative trend is indicated by a positive or negative $Z$ statistics value, respectively. The statistical significance $(\alpha)$ of the trend is shown by MAKESENS for four thresholds, i.e., $\alpha=0.001, \alpha=0.01, \alpha=0.05$ and $\alpha=0.1$.

The Sen's nonparametric method allows the estimation of the linear trend slope (as change per year). It corresponds to $Q$ in a continuous monotonic increasing or decreasing function of time $f(t)$ : $f(t)=Q+B$, where $B$ is a constant.

According to Salmi et al. (2002), Sen's method is based on the equation

$$
Q_{i}=\frac{x_{j}-x_{k}}{j-k}
$$

where $j>k$ and $i=1, \ldots, N ; x_{j}$ and $x_{k}$ are data values at times $j$ and $k$. For $n$ values in series $x$, there will be $N=n(n-1) / 2$ values of $Q$.

The Sen's estimator of the slope is the median of these $N$ values of $Q_{i}$. The $N$ values of $Q_{i}$ are ranked from the smallest to the largest, and the Sen's estimator is

$$
Q=Q_{[(N+1) / 2]} \text { if } N \text { is odd }
$$

or

$$
Q=\frac{1}{2}\left(Q_{[N / 2]}+Q_{[(N+2) / 2]}\right) \quad \text { if } N \text { is even. }
$$

In the third step, statistical relationships on three temporal scales (annual, seasonal, monthly) between climate parameters (rainfall, PET, CWB) and streamflow (SFR) were quantified by using
Spearman's test. As the data did not have a normal distribution (especially the hydrological data, which showed apparent distribution asymmetries), and the Pearson correlation coefficient could not be computed, Spearman's rank correlation coefficient $\left(R_{s}\right)$ was used, based on the relationship (Dragomirescu 1998)

$$
R_{s}=1-\frac{6 \times \sum_{i=1}^{N}\left(X_{i}-Y_{i}\right)}{N \times(N-1)},
$$

where $X_{i}$ and $Y_{i}$ are the ranks of the two variables, and $N$ is the sample size (number of pairs).

The Student test $\left(t_{v}\right)$ was used in order to test the statistical significance, based on the equation (Dragomirescu 1998):

$$
t_{v}=R_{s} \times \sqrt{\frac{N-2}{1-R_{s}^{2}}} \sim t_{N-2} .
$$

The test has a $t$ (Student) distribution with $v=$ $N-2$ degrees of freedom, and the significance of parameters is the same as for the previous equation. Reference values of the Student test were computed for the significance levels 0.05, 0.01 and 0.001 .

In order to conduct the analyses, climatic and hydrological data were clustered according to the smallest distance between stations, thus resulting in five couples of hydroclimatic data: Drobeta Turnu Severin-Corlatel, Calafat-Cujmir, CraiovaDragoia, Bechet-Goicea and Bailesti-Afumati (figure 1b). It was considered that this hydroclimatic clustering has best reflected the most likely relationship between the weather and gauging stations (located in relatively homogeneous landform conditions) available in the present study.

\section{Results}

\subsection{Hydroclimatic variability}

The analysis of climatic water balance (CWB) and streamflow rate (SFR) variability through the BoxWhisker plot method highlighted particular situation for each indicator and for each temporal scale (figure 3). With regard to annual values, CWB distributions for all stations show a high box, without any extreme values, except for 1-2 outliers. Seasonally, the interquartile interval (IQR) is not very well developed anymore, with an average number of 2 outliers per season. It can be noticed that, for this parameter, neither the annual nor the seasonal distributions have any extreme values, except for a single one in winter (at Craiova station), which means that the distributions are generally, relatively uniform (figure $3 \mathrm{a}, \mathrm{c}, \mathrm{e}, \mathrm{g}, \mathrm{i}$ ). 

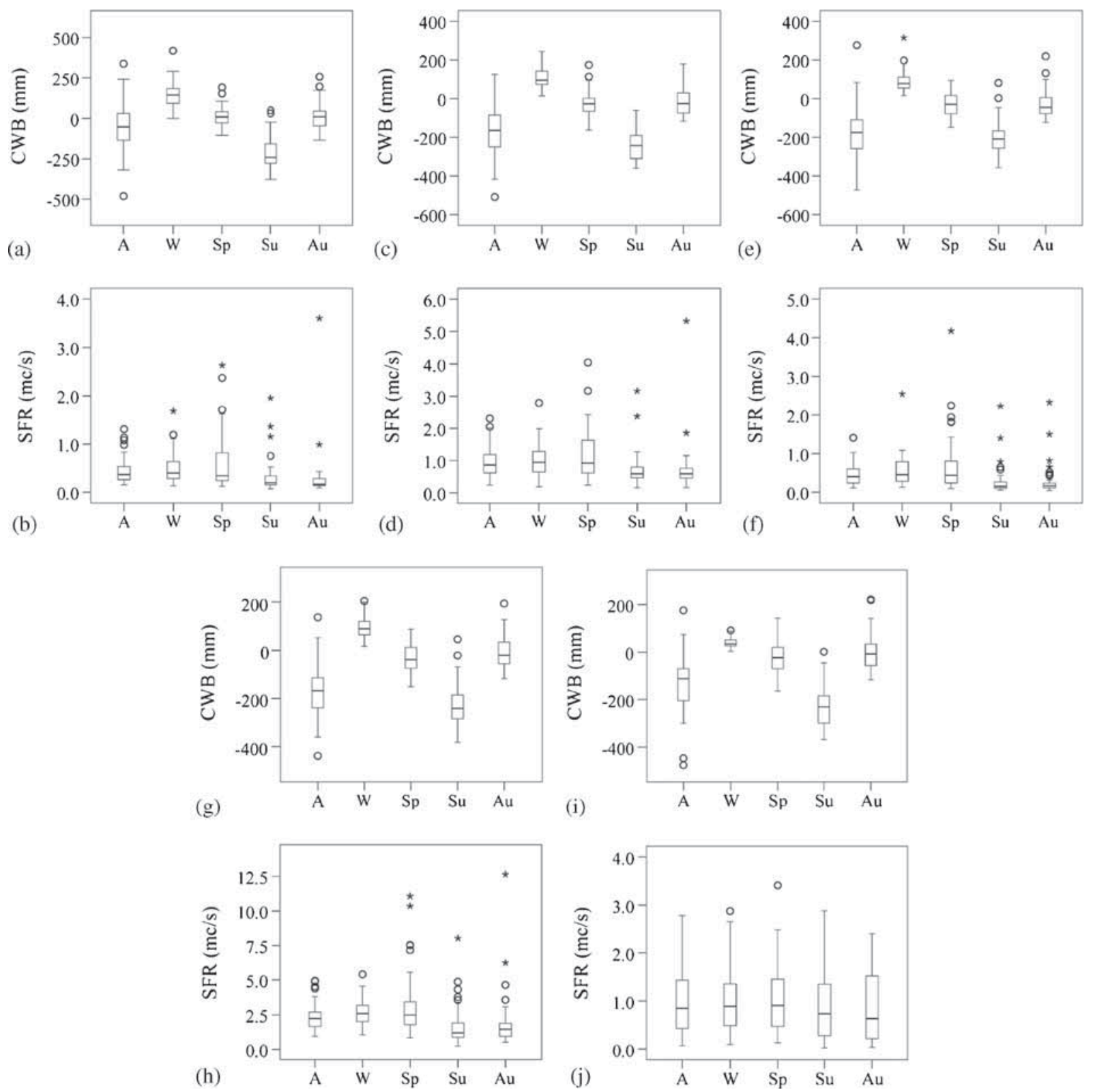

Figure 3. Annual (A) and seasonal (W: winter, Sp: spring, Su: summer, Au: autumn) climatic water balance (CWB) and streamflow rate (SFR) variability at (a, b) Drobeta Turnu Severin-Corlatel, (c, d) Calafat-Cujmir, (e, f) Craiova-Dragoia, $(\mathbf{g}, \mathbf{h})$ Bechet-Goicea and (i, j) Bailesti-Afumati data couples (o: outliers, *: extreme values).

For the hydrological parameter (SFR), both annually and seasonally, the median is not positioned in the center of the box (except for the winter seasons at Cujmir, Goicea and Afumati stations), which indicates that the probability distribution is not normal, but asymmetric (figure $3 \mathrm{~b}, \mathrm{~d}, \mathrm{f}, \mathrm{h}, \mathrm{j}$ ). The most extreme values were recorded at the Corlatel and Dragoia stations. Moreover, SFR variability shows that the IQR is narrower especially in summer and autumn at all stations (except for the Afumati station), and the median is small, which points to a reduced streamflow rate in these seasons. Conversely, in spring, the IQR is wider at all stations, as the SFR has a larger variance and a higher median value.
A relatively high SFR variability can, therefore, be noticed, as opposed to the CWB, considering the visibly higher number of extreme values. At the same time, it can be stated that the distribution of the CWB values somewhat approaches a normal distribution, unlike the SFR hydrologic indicator, the distribution of which is asymmetrical.

The CWB and SFR annual variation analysis between 1961 and 2009, based on the vector grid method, highlighted oscillation changes, especially in the last two to three decades (figure 4).

While both CWB and SFR values had apparent decreases after 1985, there are certain monthly differences for each parameter. In order to represent these differences graphically, equal intervals were 
I II III IV V VIVIIVIIIX X XIXII

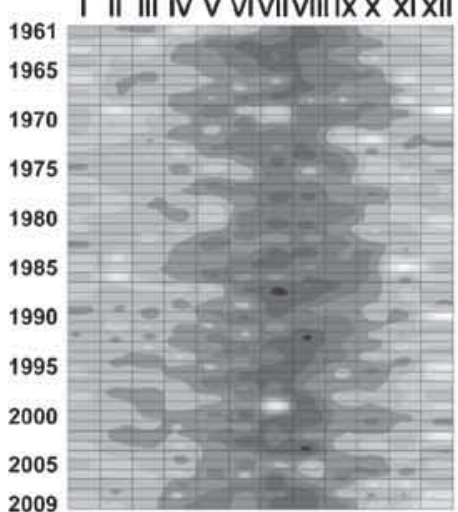

(a)

I II III IV V VIVIIVIIIIX X XIXII

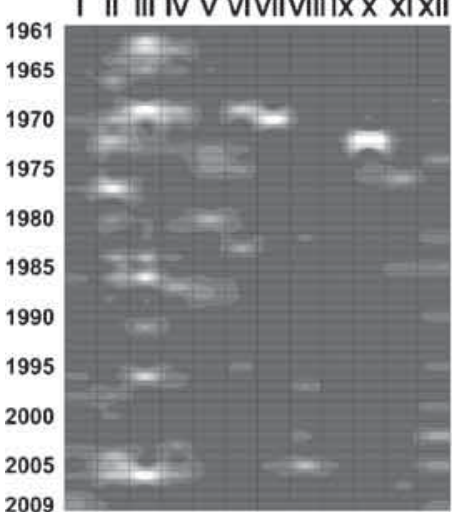

(b)

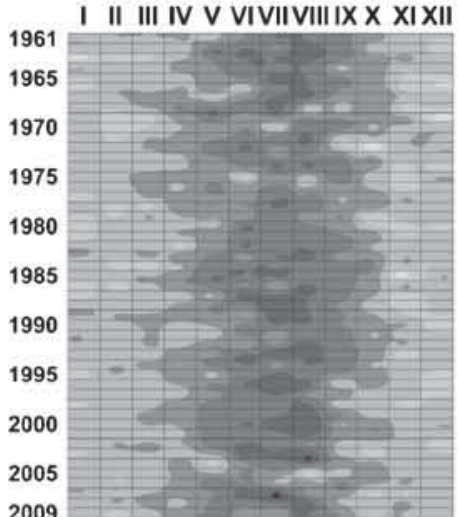

(g)

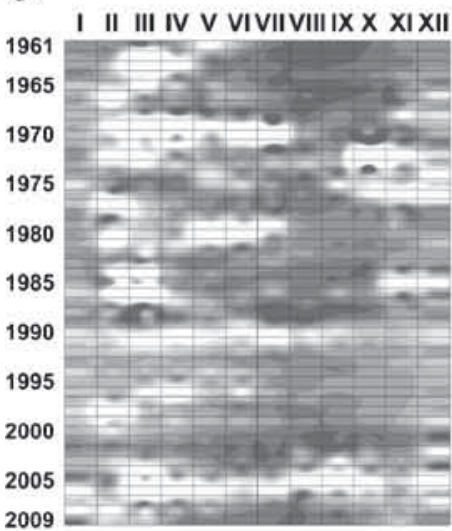

(h)

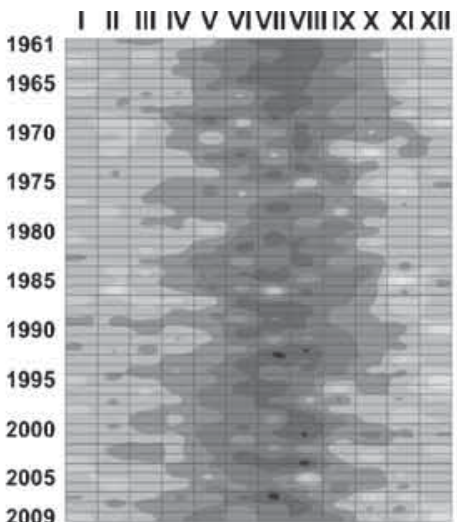

(c)

I II III IV V VIVIIVIIIIX X XIXII

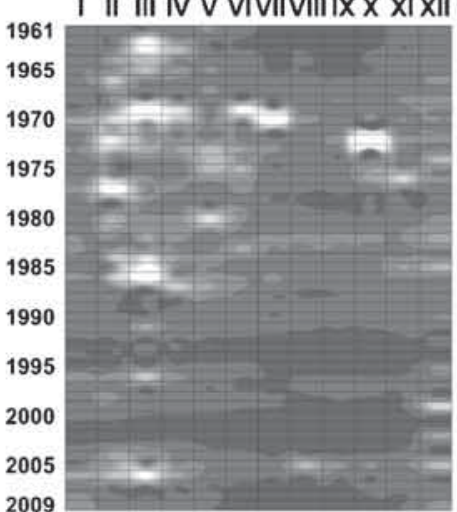

(d)

I II III IV V VIVIIVIIIIXX XIXII

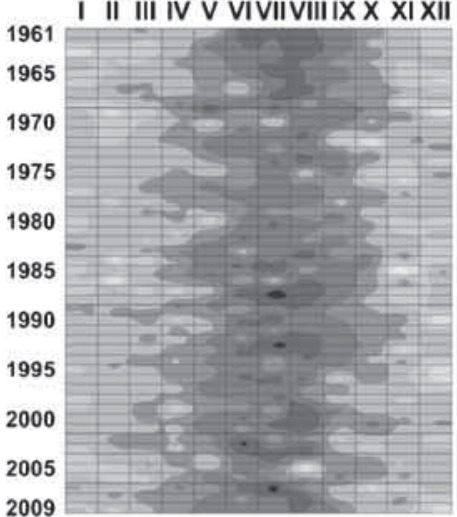

(i)

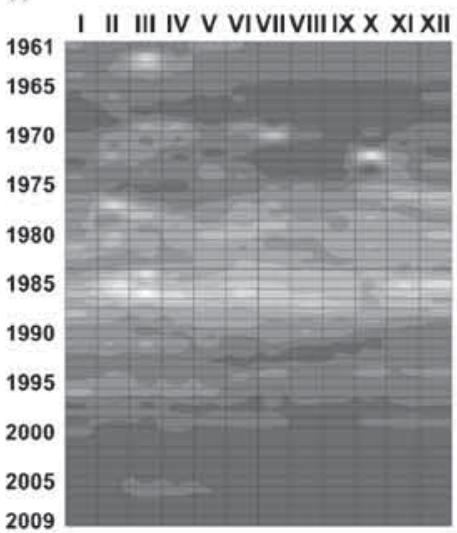

(j)
I II III IV V VIVIIVIIIIXX XIXII

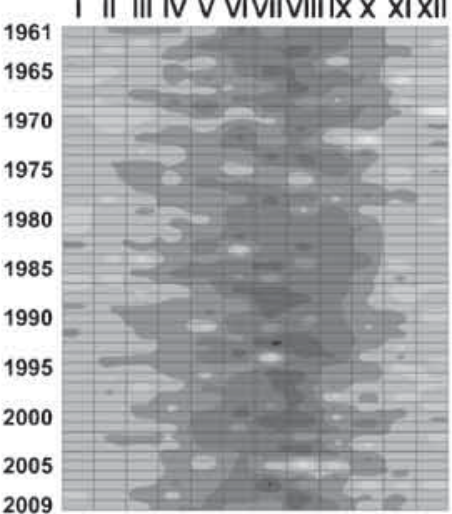

(e)

I II III IV V VIVIIVIIIIX X XIXII

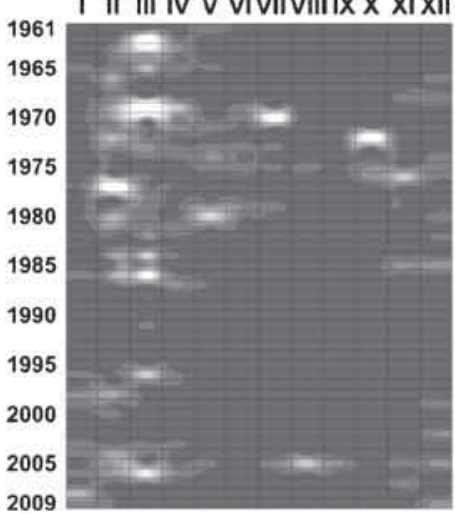

(f)
a) CWB Drobeta
b) SFR Corlatel
c) CWB Calafat
d) SFR Cujmir
e) CWB Craiova
f) SFR Dragoia
g) CWB Bechet
h) SFR Goicea
i) CWB Bailesti
j) SFR Afumati

Figure 4. Hydroclimatic variability between 1961 and 2009, for the (a, b) Drobeta (Turnu Severin)-Corlatel, (c, d) CalafatCujmir, (e, f) Craiova-Dragoia, (g, h) Bechet-Goicea and (i, j) Bailesti-Afumati data couples. 
established for CWB $(50 \mathrm{~mm})$ and $\operatorname{SFR}\left(0.5 \mathrm{~m}^{3} / \mathrm{s}\right)$ values in variability graphs, which is necessary for comparing oscillations of the analysed data clusters. Thus, for the CWB, a decrease can be noticed especially after 1990, in summer months, when deficit values start exceeding the $-150 \mathrm{~mm}$ threshold. Also, other important deficit intervals (e.g., between -100 and $-150 \mathrm{~mm}$ ) become increasingly apparent over the last two to three decades. The average streamflow (SFR) decreased especially in spring months when, for instance, the frequency of water discharges exceeding the $2 \mathrm{~m}^{3} / \mathrm{s}$ threshold significantly decreased after 1990 in all analysed cases (figure 4).

Even though the most significant changes of the two parameters occurred in different seasons, due to annual climatology and hydrologic regimes, there are obvious similarities in numerous cases of hydroclimatic variations. The results obtained through the grid method show a clear link between CWB and SFR oscillations, in numerous instances. For example, for the Drobeta-Corlatel couple (figure 4a, b), the 1970-1975 interval CWB has low values during summer months (some even positive values

Table 3. Hydroclimatic trend characteristics at annual, seasonal (W: winter, Sp: spring, Su: summer, Au: autumn) and monthly $(I, \ldots, X I I$ - months of the year) scales, at the five weather and hydrometric stations, resulting from the MannKendall (MK) test/Sen's slope (slp.) method.

\begin{tabular}{|c|c|c|c|c|c|c|c|c|c|c|c|c|}
\hline & & MK test/ & Climat & ic water b & alance (m & $(\mathrm{m})-\mathrm{C}$ & WB & & reamflow r & ate $\left(\mathrm{m}^{3} / \mathrm{s}\right)$ & - SFR & \\
\hline Scale & & Sen's slp. & Drobeta & Calafat & Craiova & Bechet & Bailesti & Corlatel & Cujmir & Dragoia & Goicea & Afumati \\
\hline Annual & & Test Z & $-1.70^{+}$ & -0.11 & $-1.97^{*}$ & -1.06 & -0.96 & -1.53 & $-3.11^{* *}$ & $-2.59 * *$ & -0.28 & $-2.31^{*}$ \\
\hline & & Sen's slp. & -2.48 & -0.15 & -2.42 & -1.09 & -1.11 & 0.00 & -0.01 & -0.01 & 0.00 & -0.01 \\
\hline Seasonal & $\mathrm{W}$ & Test Z & -0.92 & -0.75 & -0.87 & -1.23 & -0.97 & 0.77 & -1.49 & -0.54 & 0.82 & $-2.42^{*}$ \\
\hline & & Sen's slp. & -0.71 & -0.40 & -0.32 & -0.54 & -0.50 & 0.00 & -0.01 & 0.00 & 0.01 & -0.01 \\
\hline & $\mathrm{Sp}$ & Test Z & $-2.63^{* *}$ & $-2.70 * *$ & -1.63 & -0.78 & $-2.37^{*}$ & $-2.42 *$ & $-3.54^{* * *}$ & $-3.26^{* *}$ & -0.77 & $-2.73^{* *}$ \\
\hline & & Sen's slp. & -1.66 & -1.16 & -0.90 & -0.51 & -1.58 & -0.01 & -0.02 & -0.01 & -0.01 & -0.02 \\
\hline & $\mathrm{Su}$ & Test Z & -0.65 & 0.06 & -1.16 & -1.04 & -0.13 & 0.63 & $-2.56^{*}$ & $-2.17^{*}$ & 1.01 & $-1.96^{+}$ \\
\hline & & Sen's slp. & -0.67 & 0.06 & -0.95 & -0.90 & -0.09 & 0.00 & -0.01 & 0.00 & 0.01 & -0.01 \\
\hline & $\mathrm{Au}$ & Test Z & 0.32 & $1.73^{+}$ & 1.30 & 0.82 & 1.35 & 1.22 & $-2.59 * *$ & -0.84 & $2.78^{* *}$ & $-2.08^{*}$ \\
\hline & & Sen's slp. & 0.37 & 1.34 & 0.80 & 0.54 & 0.98 & 0.00 & -0.01 & 0.00 & 0.02 & -0.01 \\
\hline Monthly & I & Test Z & -0.38 & -0.56 & -0.25 & 0.03 & -0.30 & $2.36^{*}$ & -1.34 & -0.02 & 1.57 & -1.46 \\
\hline & & Sen's slp. & -0.13 & -0.15 & -0.05 & 0.01 & -0.08 & 0.00 & 0.00 & 0.00 & 0.02 & -0.01 \\
\hline & II & Test Z & $-1.99^{*}$ & $-2.06^{*}$ & $-2.08^{*}$ & -0.99 & $-1.90^{+}$ & -0.98 & $-2.44^{*}$ & $-2.00 *$ & -0.38 & $-2.40^{*}$ \\
\hline & & Sen's slp. & -0.66 & -0.54 & -0.46 & -0.24 & -0.57 & 0.00 & -0.02 & -0.01 & -0.01 & -0.01 \\
\hline & III & Test Z & $-1.85^{+}$ & -1.56 & -0.72 & -0.63 & $-2.22^{*}$ & $-2.38^{*}$ & $-3.39 * * *$ & $-2.82^{* *}$ & -0.77 & $-3.38^{* * *}$ \\
\hline & & Sen's slp. & -0.72 & -0.47 & -0.21 & -0.18 & -0.65 & -0.01 & -0.02 & -0.01 & -0.02 & -0.02 \\
\hline & IV & Test Z & -0.47 & -0.73 & -1.04 & -0.53 & -1.34 & -0.41 & $-2.85^{* *}$ & $-2.92^{* *}$ & 0.63 & $-2.39^{*}$ \\
\hline & & Sen's slp. & -0.15 & -0.21 & -0.26 & -0.14 & -0.49 & 0.00 & -0.01 & -0.01 & 0.01 & -0.01 \\
\hline & $\mathrm{V}$ & Test Z & -1.59 & -1.15 & -1.18 & -0.49 & -0.89 & -1.35 & $-3.19^{* *}$ & $-2.41^{*}$ & 0.22 & $-1.97^{*}$ \\
\hline & & Sen's slp. & -0.70 & -0.44 & -0.43 & -0.27 & -0.42 & 0.00 & -0.01 & 0.00 & 0.00 & -0.01 \\
\hline & VI & Test Z & 0.06 & -0.89 & -1.11 & -1.06 & -1.51 & -0.91 & $-3.24^{* *}$ & $-3.46^{* * *}$ & -0.28 & $-2.52^{*}$ \\
\hline & & Sen's slp. & 0.03 & -0.34 & -0.45 & -0.38 & -0.61 & 0.00 & -0.01 & 0.00 & 0.00 & -0.02 \\
\hline & VII & Test Z & -1.41 & 0.28 & -1.06 & -0.27 & 0.61 & $1.94^{+}$ & $-2.22^{*}$ & -1.47 & 1.29 & $-1.72^{+}$ \\
\hline & & Sen's slp. & -0.49 & 0.10 & -0.42 & -0.13 & 0.24 & 0.00 & -0.01 & 0.00 & 0.01 & -0.01 \\
\hline & VIII & Test Z & -0.53 & 1.11 & -0.66 & -0.89 & 0.44 & $2.63^{* *}$ & $-2.32^{*}$ & -1.09 & $2.72^{* *}$ & -1.38 \\
\hline & & Sen's slp. & -0.19 & 0.53 & -0.28 & -0.32 & 0.22 & 0.00 & -0.01 & 0.00 & 0.02 & -0.01 \\
\hline & IX & Test Z & 1.53 & $2.23^{*}$ & $1.70^{+}$ & 1.35 & $2.53^{*}$ & 1.58 & $-2.22^{*}$ & $-2.09^{*}$ & $2.76^{* *}$ & $-1.80^{+}$ \\
\hline & & Sen's slp. & 0.58 & 0.67 & 0.46 & 0.47 & 0.75 & 0.00 & -0.01 & 0.00 & 0.02 & -0.01 \\
\hline & $\mathrm{X}$ & Test Z & 0.04 & 1.28 & 1.63 & 1.28 & 1.04 & 1.44 & $-2.53^{*}$ & -0.19 & $3.17^{* *}$ & $-2.37^{*}$ \\
\hline & & Sen's slp. & 0.01 & 0.41 & 0.47 & 0.40 & 0.33 & 0.00 & -0.01 & 0.00 & 0.03 & -0.01 \\
\hline & XI & Test Z & -0.20 & -0.37 & -0.92 & -1.25 & -1.15 & 0.28 & $-2.88^{* *}$ & -1.16 & $2.24^{*}$ & $-2.12^{*}$ \\
\hline & & Sen's slp. & -0.07 & -0.13 & -0.22 & -0.36 & -0.29 & 0.00 & -0.01 & 0.00 & 0.02 & -0.01 \\
\hline & XII & Test Z & 0.00 & 0.04 & -0.01 & -0.66 & -0.33 & 1.30 & -1.11 & -1.12 & 0.83 & $-2.42^{*}$ \\
\hline & & Sen's slp. & -0.01 & 0.04 & -0.01 & -0.15 & -0.13 & 0.00 & 0.00 & 0.00 & 0.01 & -0.01 \\
\hline
\end{tabular}

Note: Values obtained through the Sen's slope method refer to the trends' magnitude (negative values indicate decreasing trends, while the positive values point to increasing trends); "+", “*”, “**" and "***" indicate significance at $\alpha=0.1$, 0.05, 0.01 and 0.001 level, respectively (values without these symbols indicate lack of statistical significance); 0.00 Sen's slope values are either positive or negative (they have the same sign as test $Z$ values) considering the third decimal place. 
in June, July and August), coupled with high discharges which substantially exceed the multiannual average (e.g., in July 1970, discharge values were more than 10 times higher than the multiannual average of $0.43 \mathrm{~m}^{3} / \mathrm{s}$, reaching $5.1 \mathrm{~m}^{3} / \mathrm{s}$ ). Similar observations can be made for Calafat-Cujmir, Craiova-Dragoia, Bechet-Goicea and Bailesti-Afumati, where similarities between hydroclimatic parameter variations can not only be noticed especially between 1970 and 1980, but also after 2000 (figure $4 c-d$, e-f, g-h, i-j).

\subsection{Trend analysis}

Trend analysis using the Mann-Kendall test (test $Z$ )/Sen's slope method showed particular situations for the two parameters and for the three temporal scales. Annually, while CWB values have downward trends (which indicates a climatic water deficit increase) at all five weather stations, only the ones at Drobeta Turnu Severin and Craiova are statistically significant (table 3). Using the Sen's slope method, it was found that these two stations show the highest negative rates, with values of -2.5 and $-2.4 \mathrm{~mm} / \mathrm{yr}$, when considering the annual change (table 3 ), or -121.5 and $-118.6 \mathrm{~mm} / 49 \mathrm{yrs}$, when considering the net change (the entire analysed period of 49 years) (figure 5). Seasonally, while the trends point to the same downward direction in winter and spring, they are only statistically significant especially in spring (table 3 ). Although downward trends were identified in summer (except for Calafat), and upward trends in autumn (thus highlighting a climatic deficit decrease), the only statistically significant ones were found, at Calafat station. In terms of trend magnitude, apparent negative rates were observed mainly in spring (maximum values of $(-1.7 \mathrm{~mm} / \mathrm{yr}) /(-81.3 \mathrm{~mm} / 49 \mathrm{yrs})$ at Drobeta Turnu Severin) (table 3, figure 5). With regard to monthly CWB values, trends are generally not statistically significant, with some exceptions in the February, March and September (table 3).

The SFR trend analysis reveals certain differences, especially in terms of statistical significance (it is generally more pronounced for hydrological data series, as opposed to climate data). Annual values have statistically significant downward trends for the Cujmir, Dragoia and Afumati stations (with negative rate values of $-0.6 \mathrm{~m}^{3} / \mathrm{s} / 49 \mathrm{yrs},-0.3$ $\mathrm{m}^{3} / \mathrm{s} / 49$ yrs, and $-0.5 \mathrm{~m}^{3} / \mathrm{s} / 49 \mathrm{yrs}$ ) (figure 5 ). Seasonally, both upward and downward trends
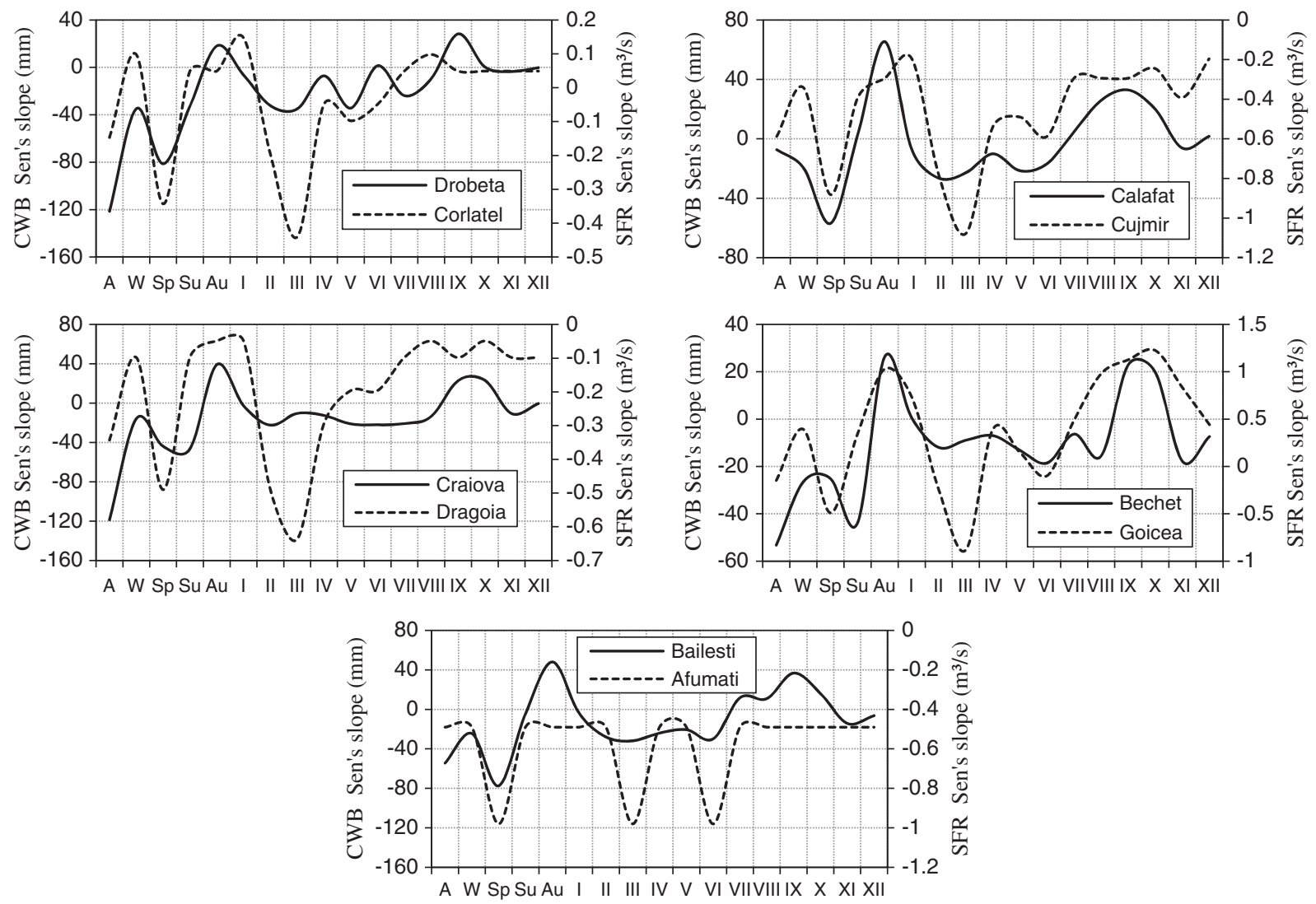

Figure 5. Variability rates in the 1961-2009 period (net change) for climatic water balance (CWB) and streamflow rate (SFR) values (A: Annual, W: winter, Sp: spring, Su: summer, Au: autumn, I, ..,XII: months of the year), at the five couples of hydroclimatic data. 
are noticed in winter, summer and autumn, with partial statistical significance. Spring is the season with the most obvious discharge decreases in all five cases analysed (the maximum level of statistical significance was found at the Cujmir station, where the negative rate peaked at $-0.02 \mathrm{~m}^{3} / \mathrm{s} / \mathrm{yr}$, or $-0.9 \mathrm{~m}^{3} / \mathrm{s} / 49 \mathrm{yrs}$ ) (table 3 , figure 5 ).

In terms of average monthly streamflow variation, two main cases can be distinguished: (1) between February and June when all hydrometric stations generally have statistically significant downward trends, and (2) from July to January, when trends are mixed, with various degrees of statistical significance (table 3 ). The maximum rate (negative) was found in March, at the Cujmir station $\left(\left(-0.02 \mathrm{~m}^{3} / \mathrm{s} / \mathrm{yr}\right) /\left(-1.1 \mathrm{~m}^{3} / \mathrm{s} / 49 \mathrm{yrs}\right)\right)$ (table 3, figure 5).

Regarding trend (Sen's slope) similarities between the five data couples, there are differences for each case. Considering the 17 associations (1 annual, 4 seasonal and 12 monthly), while the Drobeta (Turnu-Severin)-Corlatel couple shows 53\% trend concordance (nine cases of similarity), the high percentage of opposing trends $(47 \%)$ is relative, as SFR at Corlatel has almost stationary trends (trend slope close to 0) in most instances of contrary trends (table 3). For the Calafat-Cujmir couple, trends are similar in $59 \%$ of cases, while the Craiova-Dragoia, Bechet-Goicea and BailestiAfumati couples reach a concordance rate of $82 \%$, $53 \%$, and $71 \%$, respectively. In these cases as well, there are many instances of stationarity associated with contrary trends (table 3 ).

This similarity can also be observed for net variability changes, estimated over the entire 49year period. Considering hydroclimatic variability throughout the entire period for the 17 associations, largely similar oscillations can be identified between the five data couples (figure 5). These oscillations range from $-121.5 \mathrm{~mm}$ (Drobeta Turnu Severin, annually) to $65.4 \mathrm{~mm}$ (Calafat, in autumn) for CWB values, while SFR values fall between $-1.1 \mathrm{~m}^{3} / \mathrm{s}$ (Cujmir, in March) and $1.2 \mathrm{~m}^{3} / \mathrm{s}$ (Goicea, in October) (figure 5).

\subsection{Hydroclimatic correlations}

While the analysis of correlations between climatic parameters and streamflow variations, based on Spearman rank coefficients, generally showed an apparent relationship between climatic and hydrologic parameter variabilities, there were certain differences in each temporal scale for each data couple (table 4).

For the correlation of annual values, a relationship between climatic parameters and streamflow with high significance degrees for the Calafat-Cujmir, Craiova-Dragoia and Bechet-Goicea (table 4) can be noticed. Seasonally, the highest correlations correspond to spring and summer, especially for the Calafat-Cujmir and Craiova-Dragoia couples, similar to annual-scale results. In autumn, Spearman coefficients only indicate significant correlations for the Craiova-Dragoia and Bechet-Goicea couples (table 4). For monthly values, while March has the strongest correlations, Spearman coefficients indicate a high correlation of hydroclimatic parameters in all cases (except for the Bailesti-Afumati couple) in February, May and August (table 4).

Given the fact that, between 1961 and 2009, the CWB variation was influenced by the variation of the two climatic parameters based on which its value was determined (rainfall and potential evapotranspiration), we considered it important to estimate which parameter had the bigger influence on SFR. After attempting separate correlations for rainfall-SFR and potential evapotranspiration (PET)-SFR, on annual and seasonal scales (table 4), as well as carrying out investigations on the two parameters' trends at the five weather stations (figure 6), it was found that evapotranspiration had an overall bigger influence on streamflow variability.

Annually, the evapotranspiration-SFR correlations are higher, with Spearman coefficient values ranging from -0.27 to -0.61 , with high and very high statistical significance (except for the Bechet-Goicea couple), as opposed to rainfall-SFR, where correlation coefficients are smaller, and the significance is lower (table 4).

Seasonally, there are obvious differences (table 4). The relationship between rainfall and SFR is stronger during winter; Spearman coefficients show significant correlations for three of the five analysed clusters, while the PET-SFR correlation coefficients are not significant for any of the analysed case studies.

The spring and summer seasons are relevant for highlighting the strongest relations between evapotranspiration and SFR, with Spearman coefficients reaching a maximum value of -0.72 (during the summer, for the Calafat-Cujmir couple). Autumn represents the second case in which a higher rainfall influence on the streamflow can be noticed. Although the statistical significance is generally low for both correlations of climatic parameters and SFR, when compared to the correlated data series of evapotranspiration and SFR, Spearman coefficients generally have higher values for the rainfall-SFR relationship (table 4).

The climate-streamflow relationship is also expressed by the trends of the two climatic parameters used to determine the CWB (figure 6). Although annual rainfall trends are mostly decreasing, which could explain annual streamflow trends, not all weather stations show this variability and the trends have no statistical significance (figure 6a). 
Table 4. Correlations between climatic parameter (climatic water balance - CWB, rainfall and potential evapotranspiration - PET) with average streamflow rate (SFR), for the five hydroclimatic data couples ( $n=49$ values), and the resulting Spearman coefficients.

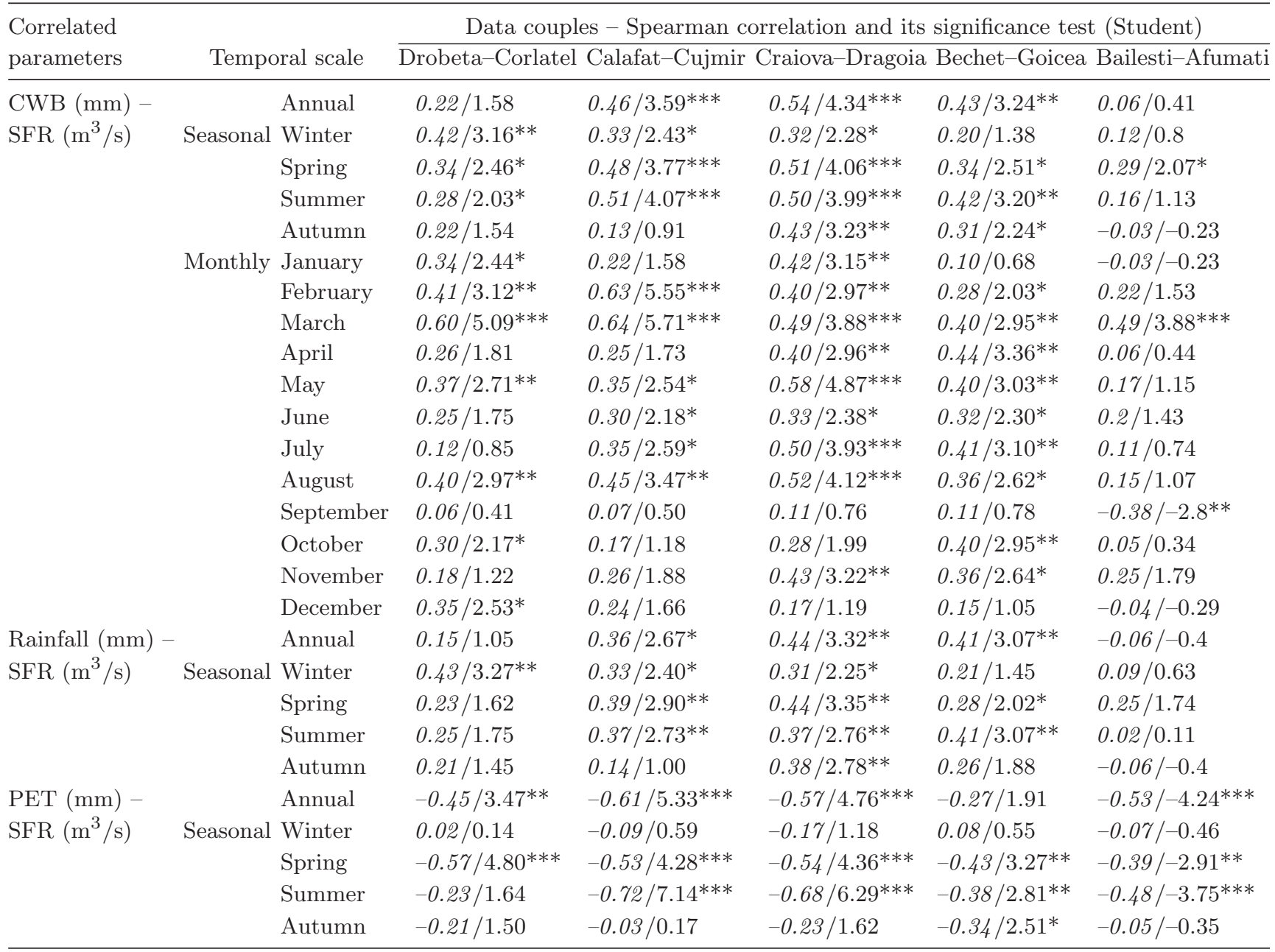

Note: Italic values are the Spearman coefficients resulting from hydroclimatic value rank correlation; regular values represent the computed $t$-test value; reference values of Student test are: for $\alpha=0.05(*), t=2.01$; for $\alpha=0.01$ ( $* *$ ), $t=2.68$; for $\alpha=0.001(* * *), t=3.51$. Greater $t$ values than the reference ones indicate statistically significant correlations.

However, evapotranspiration displays statistically significant upward trends in all cases (figure 6b). During the winter, even though evapotranspiration has upward trends, due to the season's low temperatures its values are low, as opposed to rainfall trend values (figure $6 \mathrm{c}-\mathrm{d}$ ).

In spring and summer, the strong relationship between evapotranspiration and SFR is apparent due to upward, statistically significant trends for almost all cases, and also due to this climatic parameter's high values, especially during the summer season (figures $6 \mathrm{e}-\mathrm{f}, \mathrm{g}-\mathrm{h}$ ). In autumn, the rise of rainfall amounts, coupled with an obvious decline in evapotranspiration, points to a stronger connection between rainfall and streamflow data (figure $6 \mathrm{i}-\mathrm{j}$ ).

\section{Discussions}

The results of the hydroclimatic dynamics confirm, to a certain extent, the overall nationwide state, recorded seasonally over the last decades in 44 catchments at 104 weather stations (Bîrsan 2013; Bîrsan et al. 2014). This state consists of higher streamflow rates during winter (as a result of temperature rise, which translates into a steady increase of liquid precipitations), lower discharge rates in spring (due to snow layer reduction) and summer (due to evaporation rise), as well as of higher streamflow in autumn (resulting from rainfall amount increase).

The climatic parameters' trends (rainfall and evapotranspiration), identified in the present study, are consistent with this general setting: temperature rise in winter (indirectly highlighted by increasing evapotranspiration values) (figure 6d), evapotranspiration rise in summer (figure $6 \mathrm{~h}$ ), and rainfall amount increase in autumn (figure 6i). However, streamflow trends display certain inconsistencies in winter, summer and autumn, at two/ three gauging stations. In this respect, a possible 

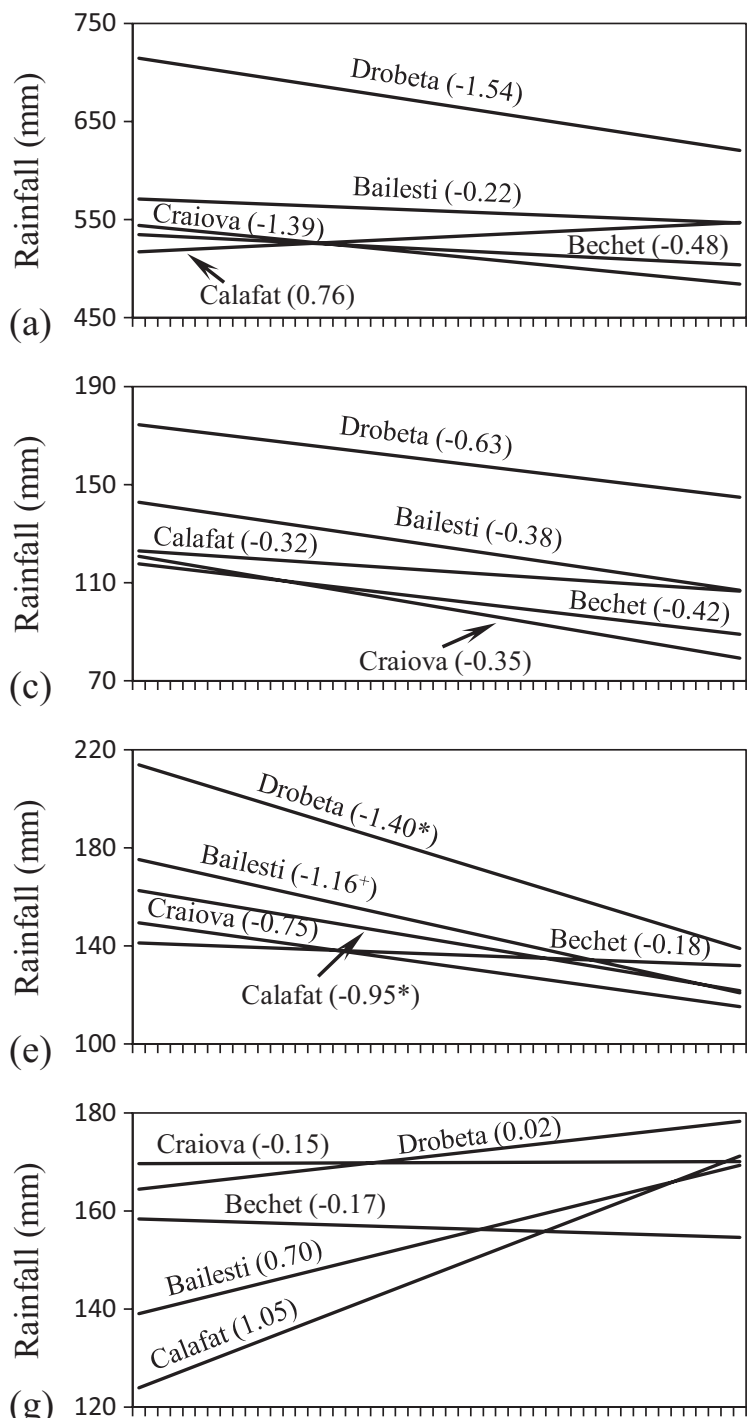

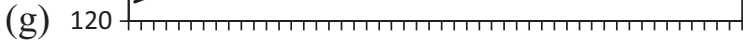

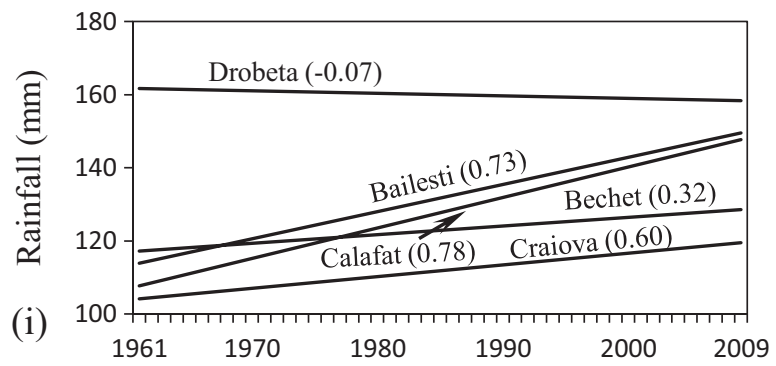

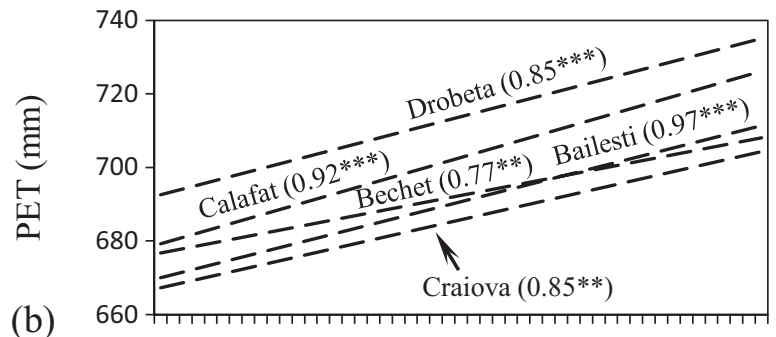

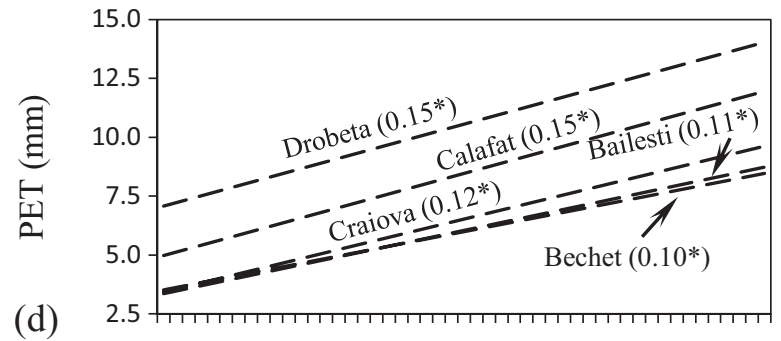

(d)

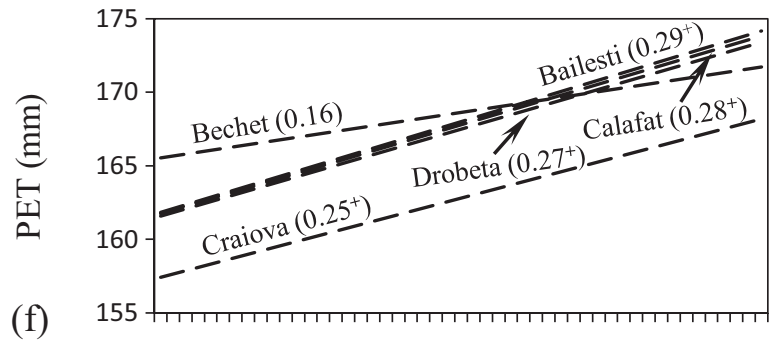

(f)
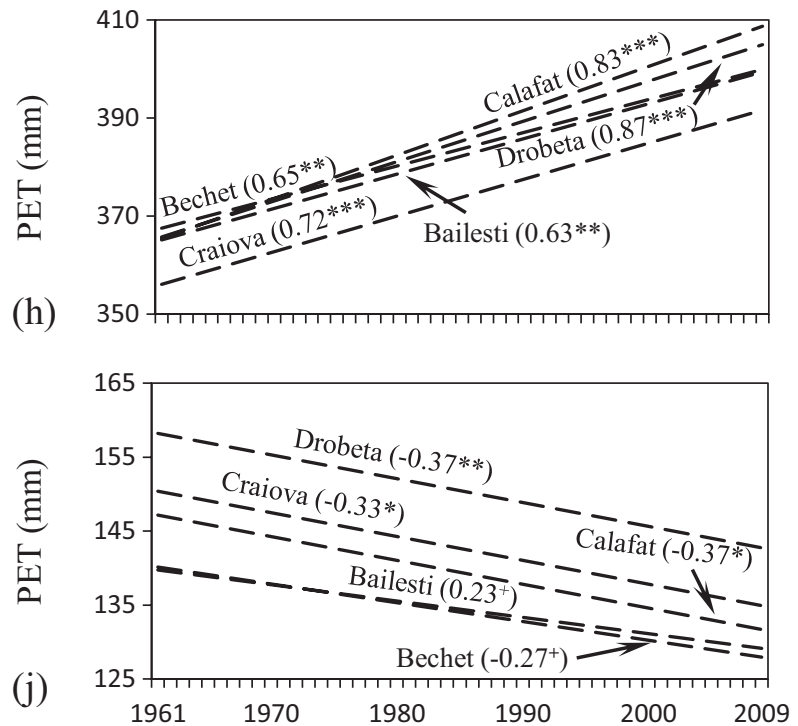

Figure 6. Rainfall and PET trends at the five weather stations, slope values (in parenthesis) and their statistical significance, $(\mathbf{a}, \mathbf{b})$ annually, (c, d) winter, (e, f) spring, (g, h) summer and (i, j) autumn. Note: '+', '*', '**' and ' $* * *$ ' indicate significance at $\alpha=0.1,0.05,0.01$ and 0.001 levels, respectively.

explanation could be provided by the two catchments' morphometric and geographic specificities, as they are located in plateau and plain regions (unlike the 44 catchments generally located in the country's mountainous areas, where river supply and streamflow conditions vary widely), as well as by human influences, which can differ from one case to another.
Nevertheless, apparent relationships were found between climatic parameters and streamflow, confirmed by the similarities of hydroclimatic trends, which exceed $50 \%$ for all cases, and especially by the results of Spearman method-based statistical correlations, which indicated relationships between the climatic and hydrological variables for more than $70 \%$ in certain cases (PET-SFR correlations). 
The inverse trends and low correlation coefficients can be explained, in most cases, by other factors (natural and anthropogenic) which influenced the streamflow in the catchments analysed over the past five decades.

The lithologic and pedologic features are among the most important natural factors controlling the streamflow. In the studied catchments, there are heavily permeable lithologic formations and soils (Pleniceanu 1999). Thus, with a permeable support, coupled with generally low slopes, infiltration is favoured, which diminishes the rainfall's direct influence on streamflow in certain cases (Ciuinel and Onţel 2012).

Also, given the fact that groundwater can contribute to streamflow by up to $45 \%$ (Pişota 2005), at times, it is difficult to identify and quantify the direct influence of the climatic factor on the streamflow, by using the trend and correlation analysis. Recent studies (Prăvălie et al. 2013) showed that groundwater levels decreased significantly over the last two decades in southwestern Romania (which causes flow reduction), in the synergistic context of potential evapotranspiration increase and the general collapse of irrigation systems, which makes the climate influence an indirect phenomenon that is not easily assessable.

Anthropological factors also play a role in streamflow dynamics. The nationwide collapse of irrigation systems, including the country's southwestern region, which occurred in 1990 (a point of political change in Romania) (Prăvălie et al. 2013; Prăvălie 2013b), led to a groundwater level decrease, at the same time with the closure of Danube's water transfer. This had a direct impact on the rivers' groundwater supply and determined the general downward trends of streamflow (identified annually) at the stations located in the plain region (of which the most heavily affected were Cujmir and Afumati stations, with $100 \%$ downward trends in all cases).

Other possible causes which influenced streamflow variation and the relationships between the analysed hydroclimatic parameters are related to changes in land use. A suitable example is the closing of the Radovan and Lipov reservoirs (located downstream of the Fantanele Lake), which were transformed into arable land after 1990 (Savin 2004). An influence can, therefore, be envisaged in Desnatui River's streamflow decrease, identified in numerous instances at the two hydrometric stations located on its course. Moreover, the streamflow of the Desnatui River was also affected by the construction of Fantanele reservoir (in 1973, with an approximate volume of 40 million $\mathrm{m}^{3}$ ) and Bistret (opened in 1972, with a 28 million $\mathrm{m}^{3}$ volume) (figure 1b). The general upward trends noticed at the Goicea station can be explained by the rise of the local base level, due to the influence of the downstream Bistret Lake.

The large scale disappearance of wetlands in the south-west region of Romania, especially after 1980 (due to the rehabilitation projects meant to expand agricultural areas) (Prăvălie 2013c), represents another possible cause that might have influenced, to some extent, the general annual streamflow decrease recorded at the five hydrometric stations.

It is important to mention that some of the results can be influenced by possible errors and uncertainties related to the quality and accuracy of the data and estimation methods. The study was based on series of average values (annual, seasonal and monthly) of certain climatic and hydrological parameters, measured directly at the stations or estimated indirectly. Therefore, although the measured data were validated by the institutions which provided them, in certain cases it is possible that determination methodology-related errors might have corrupted the data. This is more likely to have happened in the case of streamflow values, which are indirectly estimated through the river stage-discharge relationship, which is sensitive to stream cross-sectional parameters.

Also, it must be mentioned that the lack of a normal data distribution prevented a more rigorous statistical analysis, such as a regression, which would have allowed a quantitative approach of climate change impact on water resources. In the hypothetical case of data series normality, slope values would have been extracted following regression analysis, which would have allowed an estimation of the lost streamflow rate quantity associated with the one-unit amplification of climatic parameters (in this instance, a $1 \mathrm{~mm}$ increase of the climatic water deficit). Thus, the use of a higher number of weather/hydrometric stations, which would cover wider areas of southern Romania and meet the normality criterion, could make such an approach possible, in perspective.

\section{Conclusions}

The analysis of hydroclimatic dynamics in southwestern Romania, based on statistical investigations on the CWB and SFR parameters, in the period 1961-2009, showed a generally close connection between climate and streamflow and indicated an overall water resource decline in the context of climate change that affected the region over the past decades. This was highlighted by the general similitudes of hydroclimatic variations, assessed based on mean data (Box-Whisker plot analysis and vector grid method) or variability rates (estimated with the Mann-Kendall test and Sen's slope method), and especially with Spearman's rank 
correlation method which, in most cases, indicated clear connections between the five hydroclimatic data couples. Although the climate-streamflow analysis was based on a relatively limited number of stations (as a result of the limited study area), these results can be considered representative for the southwestern Romania drylands, as they generate new information on this issue in this region, not studied elaborately. Such information of hydroclimatic dynamics can be useful for the adequate management of regional water resources, in order to ensure their sustainability and adaptation to climate change.

\section{Acknowledgements}

This work was performed as a part of research supported by the UEFISCDI PN-II-PTPCCA2011-3.2 1427 (Project ECOMAGIS/No. 69/2012) and project COSMOMAR No. 58/2013 financed by STAR Program of ROSA. The authors would like to thank the anonymous reviewers for their highly constructive comments and suggestions that helped to improve this paper.

\section{References}

Bandoc G and Golumbeanu M 2010 Climate variability influence to the potential evapotranspiration regime of Sfantu Gheorghe Delta Shore; J. Environ. Prot. Ecol. 10(1) 172-181.

Bandoc G 2012 Estimation of the annual and interannual variation of potential evapotranspiration; In: Evapotranspiration - Remote Sensing and Modeling (ed.) Irmak A, InTech, Rijeka, Croatia, pp. 251-272.

Bandoc G, Dragomir E and Mateescu R 2013 Spatial analysis of potential evapotranspiration in Danube Delta; Book Series Adv. Edu. Res. 32 181-186.

Bandoc G, Mateescu R, Dragomir E, Golumbeanu M, Comănescu L and Nedelea A 2014 Systemic approach of the impact induced by climate changes on hydrothermic factors at the Romanian Black Sea Coast; J. Environ. Prot. Ecol. 15(2) 455-467.

Bandoc G and Prăvălie R 2015 Climatic water balance dynamics over the last five decades in Romania's most arid region, Dobrogea; J. Geogr. Sci. 25(11) 1307-1327.

Barnett T P, Adam J C and Lettenmaier D P 2005 Potential impacts of a warming climate on water availability in snow-dominated regions; Nature 438 303-309.

Bîrsan M V, Molnar P, Burlando P and Pfaundler M 2005 Streamflow trends in Switzerland; J. Hydrol. 314312 329.

Bîrsan M V 2013 River liquid discharge rate variability in Romania (in Romanian); PhD thesis, University of Bucharest.

Bîrsan M V, Zaharia L, Chendeş V and Brănescu E 2012 Recent trends in streamflow in Romania (1976-2005); Romanian Reports in Physics 64(1) 275-280.

Bîrsan M V, Zaharia L, Chendeş V and Brănescu E 2014 Seasonal trends in Romanian streamflow; Hydrol. Process. 28 4496-4505.
Bojariu R, Velea L, Mateescu E, Cica R D, Alexandru D, Dobrinescu A E, Bîrsan M and Dumitrescu A 2012 Local climate mechanisms related to aridization of Oltenia Plain; Ann. Univ. Craiova - Agriculture, Montanology, Cadastre Series 42(1) 70-84.

Burn D H and Hag Elnur M A 2002 Detection of hydrologic trends and variability; J. Hydrol. 255 107-122.

Busuioc A, Caian M, Bojariu R, Boroneant C, Cheval S, Baciu M and Dumitrescu A 2009 Climate regime change scenarios in Romania for the 2001-2030 period (in Romanian); National Meteorology Administration, Bucharest.

Busuioc A, Caian M, Cheval S, Bojariu R, Boroneant C, Baciu M and Dumitrescu A 2010 Climate Variability and Change in Romania (in Romanian); Pro Universitaria, Bucharest, ISBN: 978-973-129-549-7.

Cayan D R, Kammerdiener S A, Dettinger M D, Caprio J M and Peterson D H 2001 Changes in the onset of spring in the western United States; Bull. Am. Meteor. Soc. 82 399-415.

CDIAC (Carbon Dioxide Information Analysis Center) 2014 Recent Greenhouse Gas Concentrations; http://cdiac. ornl.gov/pns/current_ghg.html.

Chendeş V, Cheval S and Dumitru S 2010 The assessment of some hydrometeorological drought indices in the Bend Subcarpathians and peripheral zones; Res. J. Agri. Sci. 42(3) 60-70.

Cheval S, Baciu M and Breza T 2003 An investigation into the precipitation conditions in Romania using a GIS-based method; Theor. Appl. Climatol. 76 77-88.

Ciuinel A M and Onţel I 2012 Variability of precipitation and liquid flow in the Desnatui hydrographical basin; Water resources and wetlands, Conference Proceedings, 14-16 September 2012, Tulcea-Romania.

Ciulache S 2005 Oltenia Plain. Climate (in Romanian); Geography of Romania, Vol. V, Romanian Academy Publishing, Bucharest.

CLC 2006 Corine Land Cover (raster data); European Environment Agency, www.eea.europa.eu.

Croitoru A E, Piţicar A, Dragotă C S and Burada D C 2013 Recent changes in reference evapotranspiration in Romania; Global Planet. Change 111 127-132.

Crueger T, Roeckner E, Raddatz T, Schnur R and Wetzel P 2008 Ocean dynamics determine the response of oceanic $\mathrm{CO}_{2}$ uptake to climate change; Clim. Dyn. 31 $151-168$.

Dai A, Qian T, Trenberth K E and Milliman J D 2009 Changes in continental freshwater discharge from 1948 to 2004; J. Climate 22(10) 2773-2792.

Danberg J 2012 Changes in runoff time series in Thuringia, Germany - Mann-Kendall trend test and extreme value analysis; Adv. Geosci. 31 49-56.

Dhital Y P, Tang Q and Shi J 2013 Hydroclimatological changes in the Bagmati River Basin, Nepal; J. Geogr. Sci. 23(4) 612-626.

Dragomirescu L 1998 Biostatistics for dummies (in Romanian); Constelatii Press, Bucharest, Romania.

Dumitraşcu M 2006 Landscape changes in Oltenia Plain (in Romanian); Romanian Academy Publishing House Bucharest.

Fu G, Chen S, Liu C and Shepard D 2004 Hydro-climatic trends of the Yellow River Basin for the last 50 years; Climatic Change 65 149-178.

Genta J L, Perez-Iribarren G and Mechoso C R 1998 A recent increasing trend in the streamflow of rivers in southeastern South America; J. Climate 11 2858-2862.

Ghioca M 2008 Physical assessment of climatic impact on hydrologic extremes (in Romanian); PhD thesis, University of Bucharest, Physics. 
Ghioca M 2009 Drought monitoring using self-calibrating Palmer's indices in the southwest of Romania; Romanian Reports in Physics 61(1) 151-164.

Gilbert R O 1987 Statistical methods for environmental pollution monitoring; Van Nostrand Reinhold, New York.

Gou X, Chen F, Cook E, Jacoby G, Yang M and Li J 2007 Streamflow variations of the Yellow River over the past 593 years in western China reconstructed from tree rings; Water Resour. Res. 43 W06434.

Groisman P Y, Knight R W and Karl T R 2001 Heavy precipitation and high streamflow in the contiguous United States: Trends in the 20th century; Bull. Am. Meteor. Soc. 82 219-246.

Hannaford J, Buys G, Stahl K and Tallaksen L M 2013 The influence of decadal-scale variability on trends in long European streamflow records; Hydrol. Earth Syst. Sci. Discuss. 10 1859-1896.

He B, Miao C and Shi W 2013 Trend, abrupt change, and periodicity of streamflow in the mainstream of Yellow River; Environ. Monit. Assess. 185 6187-6199.

Hodgkins G A, Dudley R W and Huntington T G 2003 Changes in the timing of high river flows in New England over the 20th century; J. Hydrol. 278 244-252.

Huang J, Sun S and Zhang J 2013 Detection of trends in precipitation during 1960-2008 in Jiangxi province, southeast China; Theor. Appl. Climatol. 114 237-251.

IPCC 2007 Climate Change 2007: The Physical Science Basis; Contribution of Working Group I to the Fourth Assessment Report of the Intergovernmental Panel on Climate Change; Cambridge University Press, Cambridge, 996p.

JWD (Jiu Water Directorate) 2014 Data series regarding average monthly flow rates of the Drincea River (at the Corlatel and Cujmir gauging stations) and the Desnatui river (at the Dragoia and Goicea gauging stations) (19602009).

Kahya E and Kalayci S 2004 Trend analysis of streamflow in Turkey; J. Hydrol. 289 128-144.

Kendall M G 1975 Rank Correlation Methods; Charles Griffin, London.

Klein Tank A M G et al. 2002 Daily dataset of 20thcentury surface air temperature and precipitation series for the European climate assessment; Int. J. Climatol. 22 1441-1453.

Kolbert E 2011 Enter the Anthropocene: Age of man; Natl. Geogr. 219 60-77.

Liu W, Cai T, Fu G, Zhang A, Liu C and Yu H 2013 The streamflow trend in Tangwang River basin in northeast China and its difference response to climate and land use change in sub-basins; Environ. Earth Sci. 69 51-62.

Liu H, Li Y, Josef T, Zhang R and Huang G 2014 Quantitative estimation of climate change effects on potential evapotranspiration in Beijing during 1951-2010; J. Geogr. Sci. 24(1) 93-112.

Ling H, Xu H, Shi W and Zhang Q 2011 Regional climate change and its effects on the runoff of Manas River, Xinjiang, China; Environ. Earth Sci. 64 2203-2213.

Lins H F and Slack J R 1999 Streamflow trends in the United States; Geophys. Res. Lett. 26 227-230.

Ma H, Yang D, Tan S K, Gao B and Hu Q 2010 Impact of climate variability and human activity on streamflow decrease in the Miyun Reservoir catchment; J. Hydrol. $389317-324$.

Mann H B 1945 Non-parametric tests against trend; Econometrica 13 245-259.

Marin L, Birsan M V, Bojariu R, Dumitrescu A, Micu D M and Manea A 2014 An overview of annual climatic changes in Romania: Trends in air temperature, precipitation, sunshine hours, cloud cover, relative humidity and wind speed during the 1961-2013 period; Carpath. J. Earth Env. 9(4) 253-258.

Martin H and Buishand T A 2012 Multi-model analysis of RCM simulated 1-day to 30-day seasonal precipitation extremes in the Czech Republic; J. Hydrol. 412(413) $141-150$.

Milly P C D, Dunne K A and Vecchia A V 2005 Global pattern of trends in streamflow and water availability in a changing climate; Nature 438(17) 347-350.

Mitof I and Prăvălie R 2014 Temporal trends of hydroclimatic variability in the lower Buzău catchment; Geographia Technica 1 87-100.

Molyneux N, da Cruz G R, Williams R L, Andersen R and Turner N C 2012 Climate change and population growth in Timor Leste: Implications for food security; $A M B I O$ $41823-840$.

Neculau G and Zaharia L 2009 Mean rainfall and streamflow rate variability trends in Trotus catchment (in Romanian); Geography Reports 13 249-254.

NIHWM (National Institute of Hydrology and Water Management) 2014 Morphometric data of the Drincea and Desnatui rivers.

NMA (National Meteorological Administration) 2014 Data series regarding average monthly temperatures and monthly precipitation quantities at the Calafat and Bechet weather stations (1961-2009).

Palizdan N, Falamarzi Y, Huang Y F, Lee T S and Ghazali A H 2015 Temporal precipitation trend analysis at the Langat River Basin, Selangor, Malaysia; J. Earth Syst. Sci. 124 1623-1638.

Pasquini A I and Depetris P J 2007 Discharge trends and flow dynamics of South American rivers draining the southern Atlantic seaboard: An overview; J. Hydrol. 333 385-399.

Păltineanu C, Mihăilescu I F, Seceleanu I, Dragotă C S and Vasenciuc F 2007 Using aridity indexes to describe some climate and soil features in Eastern Europe: A Romanian case study; Theor. Appl. Climatol. 90 263-274.

Păltineanu C, Mihăilescu I F, Prefac Z, Dragotă C S, Vasenciuc F and Nicola C 2009 Combining the standardised precipitation index and climatic water deficit in characterising droughts: A case study in Romania; Theor. Appl. Climatol. 97 219-233.

Perju E R, Balin D, Lane S and Zaharia L 2013a Climate change impacts on water balance in the Romanian Carpathians: More droughts but fewer floods? Geophysical Research Abstracts 15, EGU2013-8284, European Geosciences Union-General Assembly, Vienna.

Perju E R, Zaharia L, Balin D and Lane S 2013b Hydrological response to climate changes in Bucegi Mountains; Volume of abstracts, Annual Scientific Conference 'Water Resources Management under Climate and Anthropogenic Changes', 23-26 September, Bucharest, pp. 98-99.

Peterson B J, Holmes R M, McClelland J W, Vorosmarty C J, Lammers R B, Shiklomanov A I, Shiklomanov I A and Rahmstorf S 2002 Increasing river discharge to the Arctic Ocean; Science 298 2171-2173.

Pişota I 2005 Oltenia Plain. Waters (in Romanian); Geography of Romania, Vol. V; Romanian Academy Publishing, Bucharest.

Pleniceanu V 1999 Waters in Oltenia Plain (in Romanian); Universitaria Publishing, Craiova.

Prăvălie R 2013a Climate issues on aridity trends of southern Oltenia in the last five decades; Geographia Technica 17(1) 70-79.

Prăvălie R 2013b Aspects regarding spatial and temporal dynamic of irrigated agricultural areas from Southern Oltenia in the last two decades; Present Environment and Sustainable Development 7(2) 133-143. 
Prăvălie R 2013c Considerations about the reduction of marshes in Southern Oltenia; Geographia Technica 8(2) 71-79.

Prăvălie R, Peptenatu D and Sîrodoev I 2013 The impact of climate change on the dynamics of agricultural systems in south-western Romania; Carpath. J. Earth Env. 8(3) 175-186.

Prăvălie R, Peptenatu D and Sîrodoev I 2014a Changes in the forest ecosystems in areas impacted by aridization in south-western Romania; J. Environ. Health Sci. Eng. 122.

Prăvălie R, Sîrodoev I and Peptenatu D 2014b Detecting climate change effects on forest ecosystems in south-western Romania using Landsat TM NDVI data; J. Geogr. Sci. 24(5) 815-832.

Prăvălie R and Bandoc G 2015 Aridity variability in the last five decades in the Dobrogea region, Romania; Arid Land Res. Manag. 29(3) 265-287.

Prăvălie R, Mitof I, Zaharia L and Bandoc G 2015 Hydroclimatic trends in southwestern Romania between 1961 and 2009 (in French); XXVIIIe Colloque de l'Association Internationale de Climatologie, Liège, Belgium, http:// www.climato.be/aic/colloques/actes/ACTES_AIC2015/ 5\%20Variabilites\%20et\%20aleas\%20climatiques/095-PRA VALIE-585-590.pdf.

Prăvălie R, Patriche C V, Sîrodoev I, Bandoc G, Dumitraşcu M and Peptenatu D 2016 Water deficit and corn productivity during the post-socialist period. Case study: Southern Oltenia drylands, Romania; Arid Land Res. Manag. 30, doi: 10.1080/15324982.2015.1091399.

Qi W, Zhang Y, Gao J, Yang X, Liu L and Khanal N R 2013 Climate change on the southern slope of Mt. Qomolangma (Everest) region in Nepal since 1971; J. Geogr. Sci. 23(4) 595-611.

Rîmbu N, Boroneant C, Buta C and Dima M 2002 Decadal variability of the Danube river flow in the lower basin and its relation with the North Atlantic Oscillation; Int. J. Climatol. 22 1169-1179.

Reiter A, Weidinger R and Mauser W 2012 Recent climate change at the upper Danube - A temporal and spatial analysis of temperature and precipitation time series; Climatic Change 111 665-696.

Sabzevari A A, Zarenistanak M, Tabari H and Moghimi S 2015 Evaluation of precipitation and river discharge variations over southwestern Iran during recent decades; J. Earth Syst. Sci. 124 335-352.

Salmi T, Määttä A, Anttila P, Ruoho-Airola T and Amnell T 2002 Detecting trends of annual values of atmospheric pollutants by the Mann-Kendall test and Sen's slope estimates - the Excel template application MAKESENS; ISBN 951-697-563-1, Finnish Meteorological Institute, Helsinki, Finland.

Sandu I, Pescaru V I, Poiana I, Geicu A, Candea I and Tastea D 2008 The climate of Romania (in Romanian); Romanian Academy Publishing, Bucharest, Romania.

Savin C 2004 Rivers in Oltenia: Hydrologic phenomena of exceptional risk (in Romanian); Universitaria Publishing, Craiova.
Savin C 2008 Rivers of Oltenia - hydrologic monograph; Vol. I (Discharge dynamics) (in Romanian); Sitech Publishing, Craiova.

Shahid S 2011 Trends in extreme rainfall events of Bangladesh; Theor. Appl. Climatol. 104 489-499.

Singh D, Glupta R D and Jain S K 2015 Statistical analysis of long term spatial and temporal trends of temperature parameters over Sutlej river basin, India; J. Earth Syst. Sci. 124 17-35.

Ştefan S, Ghioca M, Rîmbu N and Boroneanț C 2004 Study of meteorological and hydrological drought in southern Romania from observational data; Int. J. Climatol. 24(7) 871-881.

Steffen W et al. 2011 The Anthropocene: From global change to planetary stewardship; AMBIO 40 739-761.

Sterman J D and Sweeney L D 2007 Understanding public complacency about climate change: Adults' mental models of climate change violate conservation of matter; Climatic Change 80 213-238.

Stewart I T, Cayan D R and Dettinger M D 2005 Changes toward earlier streamflow timing across western north America; J. Climate 18 1136-1155.

Thornthwaite C W 1948 An approach toward a rational classification of climate; Geogr. Rev. 38(1) 55-94.

Trabucco A and Zomer R J 2009 Global aridity index (global-aridity) and global potential evapo-transpiration (global-PET) geospatial database; CGIAR consortium for spatial information, CGIAR-CSI GeoPortal, http://www. csi.cgiar.org.

Wagholikar N K, Sinha Ray K C, Sen P N and Pradeep Kumar P 2014 Trends in seasonal temperatures over the Indian region; J. Earth Syst. Sci. 123 673-687.

Zaharia L and Gălie A 2007 Climate change and its impact on the hydrologic regime of rivers in Romania (in French); Papers of the 20th International Climatology Conference, Tunis-Carthage, 3-8 September, pp. 591-596.

Zaharia L and Beltrando G 2009 Flow rate and pluviometry variability and trends in the region of the curvature Carpathians (Romania) (in French); Geographia Technica, Spec. edn, pp. 471-476.

Zarenistanak M, Dhorde A G and Kripalani R H 2014 Trend analysis and change point detection of annual and seasonal precipitation and temperature series over southwest Iran; J. Earth Syst. Sci. 123 281-295.

Zhang X, Harvey K D, Hogg W D and Yuzyk T R 2001 Trends in Canadian streamflow; Water Resour. Res. 37 987-998.

Zhang Y, Zhang S, Xia J and Hua D 2013 Temporal and spatial variation of the main water balance components in the three rivers source region, China from 1960 to 2000; Environ. Earth Sci. 68 973-983.

Zhu J, Gao P, Geissen V, Maroulis J, Ritsema C J, Mu $\mathrm{X}$ and Zhao G 2015 Impacts of rainfall and land use on sediment regime in a semi-arid region: Case study of the Wuqi catchment in the upper Beiluo River Basin, China; Arid Land Res. Manag. 29 1-16. 